a) Szkoła Główna Służby Pożarniczej, Wydział Inżynierii Bezpieczeństwa Cywilnego, Katedra Bezpieczeństwa Wewnętrznego, Zakład Zarządzania Bezpieczeństwem i Logistyki / The Main School of Fire Service, Civil Safety Engineering Faculty, Internal Security Department, Institute of Security Management and Logistics

*Autor korespondencyjny / Corresponding author: tkeson@sgsp.edu.pl

\title{
Studiowanie na kierunku bezpieczeństwo wewnętrzne w procesie przygotowania kadr dla instytucji zajmujących się bezpieczeństwem. Badania poznawcze i porównawcze - wybrane problemy
}

Internal Security Studies in the Process of Preparing Human Resources for the Institutions Responsible for Security. Preliminary and Comparative Studies - Selected Problems

Обучение в области внутренней безопасности в процессе подготовки кадров для учреждений, занимающихся вопросами безопасности. Когнитивные и сравнительные исследования - выбранная проблематика

\begin{abstract}
Cel: Celem niniejszych rozważań jest przedstawienie wybranych wyników badań, które miały m.in. pozwolić na udzielenie odpowiedzi na pytania: Kim są studiujący na kierunku bezpieczeństwo wewnętrzne? Skąd pochodzą? Czym kierują się w wyborze kierunku studiów? Co chcieliby robić po ukończeniu studiów? Ile czasu przeznaczają na naukę własną?

Projekt i metody: Badania zrealizowano w dwóch etapach. Na przełomie lat 2014/2015 na próbie liczącej 350 studentów z pięciu uczelni przeprowadzono badania rekonesansowe, a w 2017 r. na próbie liczącej 408 respondentów z 4 uczelni - badania porównawcze. Wykorzystano metodę sondażu diagnostycznego. Materiał badawczy zebrano w kwestionariuszach ankiety, zawierających po 25 pytań, w tym 3 otwarte.

Wyniki badań: Wyniki badań ankietowych poddano analizie statystycznej w programie Statistica 10.0, przy przyjętym poziomie istotności p $\leq 0,5$, a następnie dokonano ich analizy i syntezy. Wyniki badań potwierdziły hipotezy badawcze, że studiujący na kierunkach związanych z bezpieczeństwem są przedstawicielami różnych środowisk społecznych, są zróżnicowani wiekowo i rozpoczynali studia w różnym okresie po zdaniu matury. Znaczna część studiujących, nie tylko w trybie niestacjonarnym, ale również stacjonarnym łączy studia z pracą zawodową.

Wnioski: Uzyskane w wyniku przeprowadzonych badań wyniki i wyciągnięte z nich wnioski są bardzo wartościowym materiałem - zarówno teoretycznym, jak i praktycznym. Pozwalają z jednej strony na przygotowanie przez uczelnie zmian w programach, metodach i formach kształcenia oraz przygotować się do procesu rekrutacji absolwentów szkół średnich. Z badań wynika, że w przeważającej części studiującymi na kierunku bezpieczeństwo wewnętrzne są osoby pochodzące z małych miejscowości i zasadniczą przyczyną podejmowania studiów na tych kierunkach jest chęć podjęcia pracy, w pierwszej kolejności zgodnie z kierunkiem studiów w służbach mundurowych lub w administracji publicznej. Jest również znaczna część studentów, którzy podjęli studia bez związku z przyszłą pracą. Negatywnym zjawiskiem jest fakt, że ponad 50\% studiujących przeznacza na naukę własną mniej niż 2 godziny dziennie. Stawia to pod znakiem zapytania, nie tylko poziom i wymagania stawiane przed studentami, ale również ich merytoryczne przygotowanie do podjęcia pracy.

Słowa kluczowe: bezpieczeństwo wewnętrzne, zarządzanie zasobami ludzkimi, zarządzanie ciągłością działania, studiowanie bezpieczeństwa Typ artykułu: doniesienie wstępne
\end{abstract}

Przyjęty: 31.08.2018; Zrecenzowany: 09.11.2018; Zatwierdzony: 22.11.2018;

Identyfikator ORCID autora: 0000-0002-7047-7811;

Proszę cytować: BiTP Vol. 51 Issue 3, 2018, pp. 86-103, doi: 10.12845/bitp.51.3.2018.6;

Artykuł udostępniany na licencji CC BY-SA 4.0 (https://creativecommons.org/licenses/by-sa/4.0/)

\section{ABSTRACT}

Aim: The purpose of this discussion is to present selected research results which were aimed at obtaining answers to the following questions: Who are internal security students? Where do they come from? What are they guided by in choosing their field of study? What do they intend to do after graduation? How much time do they spend on self-study? 
Design and methods: The survey was carried out in two stages. In late 2014/early 2015, a preliminary study was conducted on a sample of 350 students from five universities, and in 2017 a sample of 408 respondents from 4 universities was covered by a comparative study. The research used one of the quantitative research methods, which is a diagnostic survey. The research material was collected using a questionnaire containing 25 questions, including 3 open-ended ones.

Results: The results of the survey were analysed and synthesised following statistical analysis using the Statistica 10.0 software with the assumed significance level of $p \leq 0.5$. The study results confirmed the research hypotheses that students in areas related to safety and security come from a variety of social backgrounds, are age-diverse and started their studies at various times after passing their secondary school leaving exams. A significant number of students, not only of part-time studies but also of full-time studies, combine studies with professional work.

Conclusions: The results obtained in the study and the conclusions drawn from them provide a highly valuable source of both theoretical and practical information. They enable universities to prepare changes in the programmes, methods and forms of education and to plan the recruitment process of secondary school graduates. Research shows that the majority of students of internal security come from small towns and the main reason for undertaking studies in these fields is their intention to find a job that is primarily compatible with their field of study, in uniformed services or in public administration. There is also a significant proportion of students who have taken up studies with no relation to future work. A negative phenomenon is the fact that over $50 \%$ of students spend less than 2 hours a day on self-study. This puts into question not only the level and requirements set for students, but also their acquired level of expertise needed to pursue a professional career.

Keywords: internal security, human resources management, business continuity management, security studies

Type of article: short scientific report

Received: 31.08.2018; Reviewed: 09.11.2018; Accepted: 22.11.2018;

Author's ORCID ID: 0000-0002-7047-7811;

Please cite as: BiTP Vol. 51 Issue 3, 2018, pp. 86-103, doi: 10.12845/bitp.51.3.2018.6;

This is an open access article under the CC BY-SA 4.0 license (https://creativecommons.org/licenses/by-sa/4.0/).

\section{АННОТАЦИЯ}

Цель: целью настоящих размышлений является представление отдельных результатов исследований, которые, среди прочего, должны были дать ответ на следующие вопросы: Кем являются студенты, изучающие внутреннюю безопасность? Откуда они родом? Каковы руководящие принципы при выборе области обучения? Что они хотели бы сделать после окончания обучения? Сколько времени они уделяют собственному обучению?

Проект и методы: Исследование проводилось в два этапа. На рубеже 2014/2015 годов по выборке из 350 студентов из пяти университетов было проведено предварительное исследование, а в 2017 году по выборке из 408 респондентов из 4 университетов проводилось сравнительное исследование. Использован метод диагностического исследования. Материал исследования был собран в анкетах, содержащих 25 вопросов, в том числе 3 открытых.

Результаты исследований. Результаты анкетных опросов были подвергнуты статистическому анализу в программе Statistica 10.0 с предполагаемым уровнем значимости p $\leq 0,5$, а затем были выполнены их анализ и синтез. Результаты исследования подтвердили гипотезы исследования о том, что учащиеся на факультетах, связанных с безопасностью, являются представителями различных социальных сред, различны по возрасту и начали свои занятия в разные периоды после сдачи выпускных экзаменов. Значительная часть студентов, не только на нестационарных, но и на дневной форме обучения, совмещает учебу с профессиональной работой.

Выводы: полученные результаты и сделанные из них выводы являются очень ценным материалом - как теоретическим, так и практическим. Они позволяют, с одной стороны, подготовить изменения в программах, методах и формах обучения в университетахи подготовиться к процессу набора выпускников средней школы. Исследования показывают, что по большей части те, кто обучается на факультетах, связанных с внутренней безопасностью, - это люди из небольших городов, и главной причиной выбора студентами таких направлений обучения является их желание работать, в первую очередь, согласно выбранной области обучения, в органах безопасности или государственного управления. Существует также значительная доля студентов, которые приступили к учебе без связи с будущей работой. Негативным явлением является тот факт, что более 50\% студентов посвящают менее 2 часов в день на собственное обучение. Это ставит под вопрос не только уровень и требования, предъявляемые к студентам, но и их основную подготовкук будущей работе.

Ключевые слова: внутренняя безопасность, управление персоналом, управление непрерывностью деятельности, исследования безопасности

тип статьи: предварительный отчет

Принята: 31.08.2018; Рецензирована: 09.11.2018; Одобрена: 22.11.2018;

Идентификатор ORCID автора: 0000-0002-7047-7811;

Просим ссылаться на статью следующим образом: BiTP Vol. 51 Issue 3, 2018, pp. 86-103, doi: 10.12845/bitp.51.3.2018.6;

Настоящая статья находится в открытом доступе и распространяется в соответствии с лицензией CC BY-SA 4.0 (https://creativecommons.org/ licenses/by-sa/4.0/).

\section{Wprowadzenie}

Integralną częścią systemów zapewniania bezpieczeństwa jest człowiek, który bazując na wiedzy, umiejętnościach i doświadczeniu, jest w stanie, nie tylko zarządzać i kierować tymi

\section{Background}

People are the integral part of every security management system. Knowledge, skills and experience enable them not only to manage and control such systems, but also to make 
systemami, ale podejmować kluczowe z punktu widzenia skuteczności i ciągłości ich działania decyzje. Zdolność działania w obliczu zagrożeń, a w szczególności zapewnienie jego ciągłości, zwłaszcza w sytuacjach niedoboru sił i środków, czy też w momencie, gdy parametrem krytycznym staje się czas, stawia decydenta, operatora systemu zapewniania bezpieczeństwa przed specyficznym zadaniem udowodnienia, że tworzy on wartość dodaną systemu. Stanowi on bowiem zasadniczy element zasobów każdej organizacji [1]. Dlatego też, to wiedza i umiejętności człowieka sprawiają, że c nie jest on najsłabszym ogniwem systemu.

Przygotowanie czynnika ludzkiego nabiera szczególnego znaczenia nie tylko w sytuacjach zwalczania znanych i nowo pojawiających się zagrożeń, ale jest ono istotne zwłaszcza na etapie przygotowywania wszelkiego rodzaju planów: zarządzania kryzysowego, ciągłości działania, ratowniczo-gaśniczych, ochrony i obrony w tym: ludności, infrastruktury krytycznej, obiektów o szczególnym znaczeniu dla bezpieczeństwa i obronności państwa, przeciwpożarowych, przeciwpowodziowych i wielu innych. Każda z osób funkcjonujących w systemie zapewniania bezpieczeństwa, bez względu na podmiot i przedmiot jej działania, musi zdawać sobie sprawę, że może zdarzyć się sytuacja, kiedy to jej działanie, wiedza i umiejętności mogą przyczynić się do osiągnięcia sukcesu, zlikwidowania zagrożenia i usunięcia jego skutków. Brak wiedzy i umiejętności, a także zaniechanie działania mogą spowodować negatywne skutki dla osób, mienia i środowiska.

Każdy proces dotyczący zapewniania bezpieczeństwa nie jest tylko działaniem realizowanym w sytuacji kryzysowej, ale związany jest z bieżącym zapobieganiem, przygotowaniem do działania w sytuacji kryzysowej, utrzymaniem gotowości do jak najszybszej reakcji, a po zdarzeniu odtworzeniem i przywróceniem do działania infrastruktury oraz uczynienie jej bardziej odpornej na negatywne i destrukcyjne zdarzenia. Cykl ten powinien stale doskonalony, a czynności z niego wynikające powinny opierać się na analizowaniu i diagnozowaniu zagrożeń. Osoby realizujące zadania w tym zakresie muszą zdawać sobie sprawę z faktu, że przygotowanie i utrzymanie skutecznego systemu zapewniania bezpieczeństwa, bez względu na skalę (mikro czy makro), wymaga od nich niezwykle dokładnej analizy wszelkich procesów zachodzących w systemie oraz na niego oddziałujących. Analiza ta dotyczy także relacji zachodzących między tymi procesami, a także ryzyka (w tym jego właścicieli) oraz poziomu jego akceptacji. Tylko system tworzony na podstawie takiej analizy i diagnozy oraz wynikających z nich wniosków i prognoz pozwalał będzie na możliwie najbardziej skuteczną ochronę przed zagrożeniami oraz skutkami negatywnych zdarzeń Umożliwi to podejmowanie uzasadnionych w zakresie [2]:

- funkcjonowania elementów systemu w warunkach zagrożeń oraz wdrażania mechanizmów i procedur mających ma celu ograniczenie wystąpienia zakłóceń w jego funkcjonowaniu czy też minimalizujących ryzyko przerwania jego działalności;

- działań planistycznych w zakresie przeznaczania i uruchamiania środków inwestycyjnych umożliwiających skuteczne odtworzenie zniszczonych elementów systemu.

Aby tak przygotować działanie wszelkich ogniw systemów zapewniania bezpieczeństwa, bardzo ważne jest bazowanie na odpowiednio przygotowanej kadrze. Dlatego istotne jest key decisions in the context of their effectiveness and continuity. Due to the necessity for the system to remain operational in the face of danger, and particularly to retain continuity, especially where manpower and equipment is scarce, or where time is of the essence, the decision-maker who is the security management system operator is faced with the task of proving that he or she provides added value to the system. The decision-maker forms the essential component of every organisations's resources [1]. For this reason, it is the knowledge and skills that preclude him or her from being the weakest link in the system.

Not only does the appropriate preparation of the human factor acquire special significance in situations of fighting known and new threats, but it is also important at the stage of developing plans of any type, including crisis management, business continuity, fire and rescue, security and defence of, i.a., the population, critical infrastructure, buildings of vital significance for state security and defence, firefighting, flood protection and in many other areas. Every person being part of a security management system, regardless of the subject and object of their activity, must realise that there are possible situations where their action, knowledge and skills might contribute to success, eliminating the threat or removing its effects. On the other hand, lack of knowledge or skills and inaction might endanger people, property and the environment.

Every process aimed at maintaining safety involves not only responding to emergency situations, but also ongoing prevention, preparation to action, constant preparedness to respond quickly and, after an event, the restoration and bringing back into use of infrastructure and making it more resistant to adverse and destructive events. This cycle should be constantly improved and the actions involved should be based on the analysis and identification of the risks. Individuals performing such tasks should be aware of the fact that preparing and maintaining an effective security management system, regardless of scale (micro or macro), requires a meticulous analysis of all processes occurring within and affecting the system. This analysis also involves the relationships between these processes and also the risk (including to its owners) and the level of risk acceptance. Only a system developed on the basis of such analysis and identification, and the resulting conclusions, will allow the most effective protection against risks and effects of adverse events. This will facilitate making informed decisions in terms of [2]:

- the functioning of the system's elements under conditions involving risks and the implementation of mechanisms and procedures aimed at reducing the occurrence of disruptions in its operation or minimising the risk of breaking its continuity;

- planning activities involving the designation and deployment of funds which allow the effective restoration of the damaged elements of the system.

To prepare the operation of all elements in security management systems in this way, it is essential to base it on properly trained personnel. For this reason, it is important to acquire knowledge about students in areas of security, who are the human resources to make up the future decision-making 
zdobycie wiedzy na temat studiujących na kierunkach związanych z bezpieczeństwem, którzy stanowić będą zasoby ludzkie, z których mogą wywodzić się przyszli decydenci i operatorzy systemów zapewniania bezpieczeństwa. Celom takim służyły dwa cykle badań dotyczących osób studiujących na kierunkach związanych z bezpieczeństwem - badania rekonesansowe przeprowadzone w 2015 r. i badania porównawcze w 2017 r.

\section{Student i studiowanie bezpieczeństwa - badania rekonesansowe i porównawcze. Podstawowe informacje o badaniach}

Założeniem zespołu badawczego było przeprowadzenie dwóch edycji badań ankietowych studiujących na kierunkach związanych z bezpieczeństwem. W pierwszym etapie - badania rekonesansowe, realizowane pod auspicjami Katedry Podstaw Bezpieczeństwa Uniwersytetu Warmińsko-Mazurskiego w Olsztynie, na przełomie lat $2014 \mathrm{i} 2015$. Badaniami objęto $\mathrm{N}=350 \mathrm{stu}$ diujących na pierwszym stopniu studiów w trybie stacjonarnym i niestacjonarnym, na kierunkach: bezpieczeństwo wewnętrzne (bw) i bezpieczeństwo narodowe (bn). Badania przeprowadzono na pięciu wyższych uczelniach: Akademii Obrony Narodowej w Warszawie, Akademii Pomorskiej w Słupsku, Szkole Głównej Służby Pożarniczej w Warszawie, Uniwersytecie Warmińsko-Mazurskim w Olsztynie, Wyższej Szkole Handlowej w Radomiu.

W drugim etapie - badania porównawcze, realizowane w 2017 r. pod auspicjami Katedry Bezpieczeństwa Wewnętrznego i Informatyki Państwowej Wyższej Szkoły Zawodowej w Koninie. Badaniami objęto $\mathrm{N}=408$ studiujących na studiach pierwszego stopnia, w trybie stacjonarnym i niestacjonarnym, na kierunku bezpieczeństwo wewnętrzne. Badania przeprowadzono na czterech wyższych uczelniach: Państwowej Wyższej Szkole Zawodowej w Koninie, Szkole Głównej Służby Pożarniczej, Uniwersytecie Warmińsko-Mazurskim w Olsztynie, Wyższej Szkole Informatyki i Zarządzania w Radomiu.

Wyniki badań:

- rekonesansowych (poznawczych) zostały opublikowane i omówione w 2015 r. w monografii Student i studiowanie bezpieczeństwa. Badania rekonesansowe. Raport końcowy autorstwa Tadeusza Kęsonia i Mariana Lutostańskiego (obliczenia i zestawienie danych statystycznych wykorzystanych do opracowania Raportu przygotowali: Monika Radzymińska i Wojciech Rejmer);

- porównawczych - są na etapie opracowywania.

Liczebność grup badawczych studentów kierunków związanych z bezpieczeństwem, różniła się o 58 badanych ( $w$ badaniu rekonesansowym $\mathrm{N}=350$, a $w$ badaniu porównawczym $N=408$ ). Należy zaznaczyć, że badania z 2015 r. objęły studiujących na dwóch kierunkach: bezpieczeństwo narodowe $\left(\mathrm{N}_{\mathrm{bn}}=232\right)$ i bezpieczeństwo wewnętrzne $\left(\mathrm{N}_{\mathrm{bw}}=118\right)$, a badania z 2017 r. objęły studiujących na kierunku bezpieczeństwo wewnętrzne $(\mathrm{N}=408)$. Taki bowiem kierunek studiów prowadzony był na uczelniach, których studentów włączono do badań.

Analiza uzyskanych w 2015 r. odpowiedzi jednoznacznie wskazuje, że bez względu na to, czy badani studiowali na bodies and operators of security management systems. This was the purpose of two series of surveys of people in study programmes related to security - the preliminary studies performed in 2015 and the comparative studies conducted in 2017.

\section{Students and studying security - preliminary and comparative studies. Basic information on the surveys}

The objective of the research team was to conduct two series of survey studies of students in study programmes related to security. The first stage involved a preliminary survey conducted under the auspices of the Department of Security Fundamentals of the University of Warmia and Mazury in Olsztyn, in late 2014/early 2015. The surveys involved $\mathrm{N}=350$ full-time and part-time students of the first-cycle programmes in internal security (bw) and national security (bn). The surveys were conducted at five higher education institutions: $\mathrm{Na}$ tional Defence University in Warsaw, Pomeranian University in Słupsk, the Main School of Fire Service in Warsaw, University of Warmia and Mazury in Olsztyn and Radom Academy of Economics.

The second stage involved a comparative study conducted in 2017 under the auspices of the Department of Internal Security and Information Technology of the State University of Applied Sciences in Konin. The survey involved $\mathrm{N}=408$ full-time and part-time students of first-cycle programmes in internal security and national security. The surveys were conducted at four higher education institutions: The State University of Applied Sciences in Konin, the Main School of Fire Service, the University of Warmia and Mazury in Olsztyn and the Higher School of Information Technology and Management in Radom.

The results of:

- Preliminary (exploratory) studies were published and discussed in 2015 in the monograph The student of and studying security. Preliminary studies Final report by Tadeusz Kęsoń and Marian Lutostański (the calculations and comparison of statistical data for the report were prepared by: Monika Radzymińska and Wojciech Rejmer);

- comparative studies - processing in progress.

The population of sample groups of students of security-related programmes differed by 58 respondents $(\mathrm{N}=350$ in the preliminary study and $\mathrm{N}=408$ in the comparative study). It should be noted that the surveys from 2015 covered students of two programmes: national security $\left(\mathrm{N}_{\mathrm{bn}}=232\right)$ and internal security $\left(N_{b w}=118\right)$, and the surveys from 2017 covered students of internal security $(\mathrm{N}=408)$. It was the field of study available at the higher education institutions whose students were enrolled in the studies.

An analysis of the responses obtained in 2015 indicates that regardless of whether the respondents studied national security 
kierunku bezpieczeństwo narodowe, czy bezpieczeństwo wewnętrzne, to procentowo uzyskiwane wyniki były zbliżone. Kierunek studiów nie zmieniał więc charakteru odpowiedzi.

Ponadto w analizie statystycznej i rozkładzie Chi-kwadrat Pearsona wyników badań z 2015 r. grupę badanych studiujących na obu kierunkach w znacznej części analizy traktowano łącznie $\mathrm{N}=350$. Jednocześnie analiza statystyczna wyników badań studiujących na poszczególnych kierunkach nie wskazywała istotnych rozbieżności między nimi (np. w zakresie głównej przyczyny podjęcia studiów na kierunku związanym z bezpieczeństwem, czasu, jakim student dziennie dysponuje i jaki przeznacza na samodzielną naukę) [3]. Można zatem, zdaniem autora, dokonać porównania wyników badań prowadzonych w latach 2015 i 2017.

Zestawienie liczby badanych studiujących w badaniu rekonesansowym i porównawczym w podziale na tryb i kierunek studiów oraz ze względu na płeć studiującego przedstawia tabela 1. or internal security, the percentage results were similar. The field of study did not affect the response type.

Furthermore, in the statistical analysis and Pearson's Chisquare test of the study results from 2015 the groups of students of both programmes were substantially treated as a single group $N=350$. At the same time, the statistical analysis of the results of students of each programme did not show significant discrepancies between them (e.g. in terms of the main reason for taking up studies in a security-related field and the time that students have at their disposal every day and spend on learning) [3]. According to the author, it is possible to compare the results of studies conducted in 2015 and 2017.

Table 1 presents a comparison of the number of student respondents in the preliminary and comparative studies divided by mode and programme of study and by the gender of the student.

Tabela 1. Zestawienie liczby badanych studiujących w badaniu rekonesansowym i porównawczym w podziale na tryb i kierunek studiów oraz ze względu na płeć studiującego

Table 1. Comparison of student respondents in the preliminary and comparative research, divided by the mode and programme of study and by the gender of the student

\begin{tabular}{|c|c|c|c|c|}
\hline \multirow{4}{*}{ Tryb studiów/Mode of study } & \multicolumn{4}{|c|}{ Badania/Research } \\
\hline & \multicolumn{3}{|c|}{$\begin{array}{l}\text { Rekonesansowe } 2015 \\
\text { Preliminary } 2015\end{array}$} & $\begin{array}{c}\text { Porównawcze } 2017 \text { r. } \\
\text { Comparative } 2017 \\
\end{array}$ \\
\hline & \multicolumn{4}{|c|}{ Liczba badanych/Number of respondents } \\
\hline & $\mathbf{N}$ & Nbn & Nbw & $\mathrm{N}=\mathrm{Nbw}$ \\
\hline Stacjonarne/Full-time studies & 170 & 137 & 33 & 311 \\
\hline Niestacjonarne/Part-time studies & 180 & 95 & 85 & 97 \\
\hline Ogółem/Total & 350 & 232 & 118 & 408 \\
\hline
\end{tabular}

\begin{tabular}{cc}
\hline $\begin{array}{c}\text { Bekonesansowe 2015 r. } \\
\text { Preliminary 2015 }\end{array}$ & $\begin{array}{c}\text { Porównawcze 2017 r. } \\
\text { Comparative 2017 }\end{array}$ \\
\hline Płeć studiującego/Student gender \\
\hline \multicolumn{2}{c}{ Kobiety/Female } \\
\hline $196(56 \%)$ & $199(49 \%)$ \\
\hline \multicolumn{2}{c}{ Mężczyźni/Male } \\
\hline $154(44 \%)$ & $209(51 \%)$ \\
\hline
\end{tabular}

Źródło: Dane za 2015 r. Opracowanie na podstawie danych statystycznych [4, s. 16 i 17]. Dane za 2017 r. - opracowanie własne. Source: Data for 2015 based on statistical data [4, p. 16 - 17]. Data for 2017 - own study.

Studiujących badanych było odpowiednio w 2015 r. i 2018 r. na:

- I roku studiów 127 osób (36,3\%) oraz 106 osób (26\%);

- II roku studiów 75 osób $(21,4 \%)$ oraz 138 osób (33,8\%);

- III roku studiów 148 osób (42,3\%) oraz 164 osoby $(40,2 \%)$.

Chociaż badanych studiujących na II roku studiów w $2018 \mathrm{r}$. było o 84\% więcej niż w 2015 r., to okazało się, że charakter udzielanych odpowiedzi nie zmienił trendów, które zidentyfikowane zostały w badaniach rekonesansowych 2015 r. Zdaniem autorów badań uwiarygodniło to zarówno zastosowane narzędzia badawcze, jak i uzyskane wyniki.

\section{Metody badawcze, cele badań problemy oraz hipotezy badawcze}

W obu badaniach posłużono się metodą sondażu diagnostycznego i kwestionariuszem ankiety, w którym ankietowani odpowiadali na 25 pytań, w tym:

- 23 pytania zamknięte - dotyczące: płci i wieku studiującego;, stanu cywilnego i liczby posiadanych dzieci; lat od zdania matury i podjęcia studiów; roku, trybu i kierunku studiów; miejsca: zamieszkania/pochodzenia; statusu
The students who took part in the survey in 2015 and 2018 included, respectively:

- first-year students - 127 respondents (36.3\%) and 106 respondents (26\%);

- second-year students -75 respondents (21.4\%) and 138 respondents (33.8\%);

- third-year students - 148 respondents (42.3\%) and 164 respondents (40.2\%);

Although there were $84 \%$ more respondents who were second-year students in 2018 than in 2015, it was found that the trends in the responses given did not change from the ones identified in the preliminary survey in 2015. In the opinion of the authors, it adds credibility to both the research tools used and the results obtained.

\section{Research methods, objectives, problems and hypotheses}

Both studies used the diagnostic survey method and a survey questionnaire featuring 25 questions, including:

- 23 closed-ended questions regarding the student's gender and age, marital status and number of children; years from passing the secondary school leaving exam and taking up studies, mode and programme of studies; place of residence/origin; professional sta- 
zawodowego, w tym: rodzaju wykonywanej pracy/służby; przyczyn podjęcia oraz wyboru kierunku studiów; procesu uczenia się, w tym: liczby godzin przeznaczanych na naukę własną, zainteresowania i przeznaczania czasu na naukę poszczególnych przedmiotów; zidentyfikowania przedmiotów sprawiających najwięcej trudności, preferowanych form prowadzenia zajęć oraz ich efektywności;

- 2 pytania otwarte - mające na celu podanie przyczyn problemów w przyswajaniu wiedzy z przedmiotów wymienionych przez studiującego jako trudne.

Badanie rekonesansowe/poznawcze miało na celu dostarczenie danych, które umożliwią określenie profilu studiującego na kierunkach związanych z bezpieczeństwem, sprawdzenie sformułowanych hipotez badawczych, zweryfikowanie opracowanego narzędzia badawczego oraz przygotowanie do przeprowadzenia drugiego etapu badań - badań porównawczych.

Badanie porównawcze miało na celu potwierdzenie hipotez badawczych, sprawdzenie uzyskanych wyników w badaniach rekonesansowych, potwierdzenie lub zanegowanie wniosków i trendów wyłaniających się po badaniach pierwszego etapu.

W badaniach rekonesansowych poszukiwano odpowiedzi na trzy zasadnicze pytania problemu badawczego [5, s. 8]:

1. "Czym się charakteryzuje student kształcący się na kierunku bezpieczeństwo narodowe (BN) lub bezpieczeństwo wewnętrzne (BW)?

2. Jaki jest pogląd studenta kształcącego się na kierunku BN i BW na temat studiowania bezpieczeństwa oraz jaki jest powód studiowania?

3. Czy przyjęte narzędzia i procedury badawcze są wystarczająco użyteczne do sformułowania optymalnego planu badawczego i przeprowadzenia badań właściwych?"

oraz weryfikowano trzy hipotezy badawcze [5, s. 9]:

1. „Studenci kształcący się na kierunku BN lub BW są przedstawicielami różnych środowisk społecznych (miasto, wieś), są zróżnicowani wiekowo, mają różne obowiązki rodzinne, zawodowe, które mogą wpływać na jakość studiowania.

2. Studenci kształcący się na kierunku BN lub BW nie zawsze wiążą podnoszenie kwalifikacji z przyszłą pracą zawodową, co może oznaczać, iż studiowanie bezpieczeństwa jest postrzegane jako sposób na uzyskanie dyplomu ukończenia studiów wyższych.

3. Przyjęte w badaniach rekonesansowych narzędzie badawcze i procedura badawcza mogą okazać się nieoptymalne i wymagać korekty przed przeprowadzeniem badań głównych".

Ponieważ badania rekonesansowe wykazały przydatność narzędzia badawczego, a kwestionariusz ankiety nie wymagał zmian w treści pytań, w badaniu porównawczym skupiono się na zweryfikowaniu dwóch pierwszych pytań problemu i hipotez badawczych oraz sprawdzeniu:

- czy i na ile zmieniła się charakterystyka studiującego na kierunku bezpieczeństwo wewnętrzne;

- czy i jak zmieniły się poglądy oraz powody podejmowania studiów na kierunku związanym z bezpieczeństwem.

W obu badaniach obliczenia statystyczne wykonano w programie Statistica. Wykorzystując test Chi-kwadrat Pearsona, przy poziomie istotności $p \leq 0,05$, określono, które $z$ badanych zmiennych są zależne, a które niezależne. tus, including the type of work/service; the reasons for starting and choosing a specific programme of study; the learning process, including the number of hours spent on own learning, interests and time spent studying by subject; identifying the most difficult subjects, the preferred form of classes and their effectiveness.

- 2 open-ended questions - for specifying the reasons of problems in acquiring knowledge in subjects mentioned by the student as difficult.

The preliminary study was aimed at providing data to define the profile of a student of security-related programmes, to test the specified research hypotheses and to verify the prepared research tool and to prepare the second stage of research - the comparative study.

The comparative study was aimed at confirming the research hypotheses, testing the results obtained in the preliminary study and confirming or rejecting the results and trends found at the first stage of research.

The preliminary study involved looking for answers to the three fundamental questions of the research problem [5, p. 8]:

1. "What are the characteristics of the student of national security $(\mathrm{BN})$ or internal security $(\mathrm{BW})$ ?

2. What is the opinion of the student of $B N$ or BW about studying security and what is the reason for taking up studies?

3. Are the adopted research tools and procedures sufficiently useful to define an optimal research plan and to conduct proper research?"

and the verification of three research hypotheses [5, p. 9]:

1. "The students of BN or BW come from various social backgrounds (urban and rural) and are of diverse ages, with a variety of family and professional responsibilities which might affect the quality of studying.

2. The students of BN or BW do not always associate improving their skills with future employment, which could mean that studying security is perceived as a way to obtain a university diploma.

3. The research tool and procedure adopted in the preliminary study might be suboptimal, necessitating adjustments before the main study is launched."

As preliminary studies showed the suitability of the research tool and there was no need to introduce changes in the content of questions in the survey questionnaire, the comparative study focused on verifying the first two questions and research hypotheses and verifying:

- whether and to what extent the characteristics of a student of internal security changed;

- whether and how the opinions and reasons for taking up studies in security-related programmes changed;

Both studies used Statistica software for statistical calculations. Using Pearson's Chi-square test with the significance level $p \leq 0.05$, it was determined which of the studied variables were dependent and which were independent.' 


\section{Wybrane wyniki oraz wnioski z badań rekonesansowych i porównawczych Wiek i okres rozpoczynania studiów}

Wyniki badań rekonesansowych i porównawczych dotyczące wieku studiujących oraz okresu rozpoczynania studiów (tabela 2) nie odbiegają od wyników, jakie otrzymano by badając jakikolwiek inny kierunek studiów. Najliczniejszą ponad 50\% grupę studiujących na kierunkach związanych z bezpieczeństwem stanowią studenci w przedziale wiekowym $21 \div 23$ lata, a łącznie z grupą $19 \div 20$-latków, ich procentowy udział wśród studiujących na tych kierunkach w 2017 r. w stosunku do 2015 r. $(85,2 \%)$ wzrósł o 8,9 punktów procentowych (p.p.).

Jeżeli weźmiemy pod uwagę, że jeszcze wyższy procentowo wzrost zanotowano $w$ zakresie rozpoczynania studiów - w tym samym roku co matura - o 10,1 p.p., to widzimy, że studiujący na kierunkach związanych z bezpieczeństwem nie są osobami przypadkowymi. Aby zatem pozyskać wartościowych absolwentów szkół średnich, uczelnie prowadzące kierunki związane z bezpieczeństwem będą musiały rywalizować o nich nie tylko $z$ innymi uczelniami oferującymi taki kierunek studiów (zwłaszcza w dużych miastach, gdzie kierunki związane z bezpieczeństwem prowadzone są na kilku uczelniach), ale również przedstawiać ofertę atrakcyjnych ze względu na rynek pracy specjalności, aby być konkurencyjnymi dla innych kierunków studiów. W innym wypadku pozostaje zawężenie obszaru rekrutacji do absolwentów szkół średnich, którzy zdali egzamin dojrzałości na bardzo niskim poziomie punktowym i na inne kierunki nie mieliby szans zostać przyjętymi.

\section{Selected results and conclusions from preliminary and comparative studies Age and time of taking up studies}

The results of preliminary and comparative studies regarding the age of students and the time of taking up studies (Table 2) do not differ from the results that would be obtained for any other programme. The most numerous group of security-related students (over $50 \%$ ) were students aged $21 \div 23$ years and, combined with the group of $19 \div 20$-year olds, their percentage share in the total number of students of those programmes in 2017 in relation to 2015 (85.2\%) increased by 8.9 percentage points (p.p.).

Given the fact that an even higher percentage increase was recorded for taking up studies in the same year as passing the secondary school leaving exam - of 10.1 p.p., we can conclude that students of security-related studies are not random people. To attract valuable secondary-school leavers, higher education institutions providing security-related programmes of study will have to compete for them not only with other higher education institutions offering the same programmes (especially in big cities, where security-related programmes are available at several higher education institutions), but also present a package of attractive specialisations regarding the labour market in this area, to remain competitive in relation to other fields of study. Otherwise, they would have to limit their recruitment to those secondary school leavers who have passed their exams with very low results and would not be admitted to other programmes.

Tabela 2. Przedział wiekowy studiujących i okres rozpoczynania studiów - badania rekonesansowe i porównawcze Table 2. The age range of students and the period of starting studies - preliminary and comparative research

\begin{tabular}{|c|c|c|c|c|}
\hline \multirow{2}{*}{$\begin{array}{c}\text { Badania/Research } \\
\text { Przedział wiekowy studiujących/Age range of students }\end{array}$} & \multicolumn{2}{|c|}{ Rekonesansowe/Preliminary } & \multicolumn{2}{|c|}{ Porównawcze/Comparative } \\
\hline & $\begin{array}{l}\text { Liczba studiujących/ } \\
\text { Number of students }\end{array}$ & Procent/Percent & $\begin{array}{l}\text { Liczba studiujących/ } \\
\text { Number of students }\end{array}$ & Procent/Percent \\
\hline $19 \div 20$ lat $/ 19 \div 20$ years old & 101 & 28,9 & 162 & 39,7 \\
\hline $21 \div 23$ lata/21 $\div 23$ years old & 197 & 56,3 & 222 & 54,4 \\
\hline Więcej niż 24 lata/More than 24 years old & 52 & 14,8 & 24 & 5,9 \\
\hline$(\mathrm{N})$ & 350 & 100,0 & 408 & 100 \\
\hline Rozpoczęcie studiowania/Taking up studies & $\begin{array}{l}\text { Liczba studiujących/ } \\
\text { Number of students }\end{array}$ & Procent/Percent & $\begin{array}{l}\text { Liczba studiujących/ } \\
\text { Number of students }\end{array}$ & Procent/Percent \\
\hline $\begin{array}{l}\text { W tym samym roku co matura } \\
\text { In the same year as the school-leaving exam }\end{array}$ & 228 & 65.2 & 307 & 75,3 \\
\hline Rok po maturze/A year after the school-leaving exam & 48 & 13,7 & 59 & 14,4 \\
\hline Dwa lata po maturze/Two years after the school-leaving exam & 26 & 7,4 & 23 & 5,6 \\
\hline Inna odpowiedź/Other answer & 48 & 13,7 & 19 & 4,7 \\
\hline$(\mathrm{N})$ & 350 & 100,0 & 408 & 100 \\
\hline
\end{tabular}

Źródło: Dane za 2015 r. opracowanie na podstawie danych statystycznych [4, s. 19 i 23]. Dane za 2017 r. opracowanie własne. Source: Data for 2015 based on statistical data [4, pp. 19 and 23]. Data for 2017 own study.

Nie należy również oczekiwać, że pozyska się wystarczającą liczbę absolwentów do prowadzenia kierunku studiów, wśród tych którzy z różnych przyczyn nie podjęli studiów bezpośrednio po maturze. Studiujących, którzy rozpoczęli studia rok lub dwa lata po maturze, było w 2015 r. łącznie 21,1\% (w 2017 r. nastąpił
In addition, it should not be expected that a sufficient number of secondary school leavers to run a course would be obtained among those who, for various reasons, did not take up studies immediately after their secondary school leaving exam. In 2015 a total of $21.1 \%$ of students began their studies one or two years 
spadek o 1,1 p.p.). Zatem, aby uczelnie wypełniły limity przyjęć musiałyby rekrutować ich 5 razy więcej niż obecnie. Można również powiedzieć, że wyczerpują się zasoby osób, które podejmują studia w okresie późniejszym (w wieku ponad 24 lat). W 2017 roku było ich tylko 5,9\%, tj. ponad 2,5 razy mniej niż w 2015 r. Znalazło to odzwierciedlenie wśród tej grupy studiujących, którzy w pytaniu o rozpoczynanie studiów udzielili „innej odpowiedzi”. Ich procentowy udział w 2017 r. wyniósł jedynie 4,7\% i był 2,9 razy mniejszy niż w 2015 r. Może to świadczyć o tym, że kończy się zasób osób, które wybierały kierunki związane z bezpieczeństwem jako studia umożliwiające uzyskanie wyższego wykształcenia, niezbędnego do obejmowania kolejnych stanowisk pracy.

\section{Miejsce zamieszkania/pochodzenia i aktywność zawodowa studiujących na kierunkach związanych z bezpieczeństwem}

Zarówno wyniki badań rekonesansowych, jak i porównawczych jednoznacznie wskazują, że naturalnym zapleczem osobowym dla uczelni prowadzących kierunki studiów związane z bezpieczeństwem są absolwenci szkół średnich pochodzący/mieszkający w wioskach (tabela 3). W każdej edycji badań stanowili oni prawie $48 \%$ ogółu studiujących.

Organy jednoosobowe i wieloosobowe uczelni oraz osoby przygotowujące i prowadzące rekrutację na studia, nawet jeżeli uczenia jest $w$ dużym mieście, $w$ żadnym przypadku nie powinni zakładać, że uda im się dokonać naboru na I rok studiów, tylko spośród mieszkańców danego miasta. Bez względu na wielkość miasta, w którym mieści się uczelnia, należy zakładać, że chętnych na podjęcie studiów spośród absolwentów szkół średnich będących zarazem mieszkańcami tych miast będzie nie więcej niż 20\%. Aby zapewnić funkcjonowanie kierunku studiów związanych z bezpieczeństwem, należy docierać do mieszkańców ościennych miejscowości.

Należy bardzo wyraźnie podkreślić, że badania z 2017 r. potwierdziły, z dokładnością do dziesiątych części procenta, procentowe udziały studiujących pochodzących z różnej wielkości miast oraz wiosek/osad wiejskich. Różnice w uzyskanych wynikach nie przekroczyły 0,9 p.p.

Taki rozkład wyników, a zwłaszcza ograniczone zainteresowanie studiowaniem na kierunkach związanych z bezpieczeństwem młodych ludzi pochodzących z miast, przy kilkukrotnie, czy nawet kilkunastokrotnie większym zainteresowaniu takim kierunkiem studiów mieszkańców wiosek potwierdza, że wciąż aktualne pozostaje hasło: „żywią i bronią”. Z drugiej jednak strony wyniki badań nie napawają optymizmem. Świadczą one między innymi o tym, że ewentualna przyszła praca w szeroko rozumianym obszarze odpowiedzialności za bezpieczeństwo nie jest priorytetem absolwenta szkoły średniej mieszkającego w mieście. Nasuwa to także następujące pytania: Czy studiowanie na kierunkach związanych z bezpieczeństwem pozwala beztrosko myśleć o przyszłości przyszłym absolwentom tych kierunków pochodzącym/mieszkającym w wioskach? Czy jest to tylko jedna $z$ form podniesienia ich prestiżu w środowisku, w którym dotychczas żyli, związanego z faktem ukończenia studiów wyższych? after their school leaving exams (this decreased by 1.1 p.p. in 2017). Therefore, for higher education institutions to fill their lists, they would have to recruit 5 times more candidates than now. It can also be said that there are fewer and fewer people who take up studies at a later time (over 24 years of age). In 2017 they accounted for only $5.9 \%$ i.e. 2.5 times less than in 2015 . This was reflected in this group of students who responded "other" to the question about taking up studies. Their percentage share in 2017 was only $4.7 \%$ and was 2.9 times smaller than in 2015 . This could mean that there are fewer and fewer people choosing security-related programmes as studies which enable them to obtain a higher education degree necessary to take up jobs on the labour market.

\section{Place of residence/origin and professional activity of students of security-related programmes}

The results of both preliminary and comparative studies clearly indicate that the natural personal capital of higher education institutions offering security-related programmes are secondary school leavers coming from or living in rural areas (Table 3 ). In both studies they comprised nearly $48 \%$ of all students.

The single-person authorities and collective bodies of higher education institutions and the people preparing and conducting the recruitment process, even if the institution is based in a large city, should not assume that they will find enough first-year students only among the residents of their city. Regardless of the size of the city in which a higher education institution is based, it should be assumed that no more than $20 \%$ of all candidates among secondary school leavers would also be the residents of those cities. To maintain security-related programmes, higher education institutions must reach the residents of the neighbouring villages and towns.

It should be clearly emphasised that the 2017 study confirmed with one decimal place accuracy, the percentage shares of students coming from various-sized towns and cities and villages/rural settlements. The differences in the obtained results did not exceed 0.9 p.p.

Such a distribution of results and especially the limited interest among young people from cities in security-related programmes paired with a several or even more than a dozen times higher interest in this field among the residents of villages confirms that the slogan "they feed and defend" is still current. On the other hand, the survey results are not a cause for optimism. One of the conclusions is that a potential future job in the broadly understood field of responsibility for security is not a priority for secondary school leavers living in cities. This also brings to mind the following questions: Do security-related studies enable their students coming from villages to look at their future with optimism? Is this only one of the ways to improve their position in their environment by graduating from a higher education institution? 
Tabela 3. Miejsce zamieszkanie/pochodzenie studenta oraz aktywność zawodowa Table 3. Place of residence/origin of the student and professional activity

\begin{tabular}{|c|c|c|c|c|}
\hline \multirow{2}{*}{$\begin{array}{c}\text { Badania/Research } \\
\begin{array}{c}\text { Zamieszkanie/Pochodzenie } \\
\text { Residence/origin }\end{array} \\
\end{array}$} & \multicolumn{2}{|c|}{ Rekonesansowe/Preliminary } & \multicolumn{2}{|c|}{ Porównawcze/Comparative } \\
\hline & $\begin{array}{l}\text { Liczba studiujących/ } \\
\text { Number of students }\end{array}$ & Procent/Percent & $\begin{array}{l}\text { Liczba studiujących/ } \\
\text { Number of students }\end{array}$ & Procent/Percent \\
\hline Miasto > 200 tys. mieszkańców/City > 200 thousand inhabitants & 21 & 6,0 & 22 & 5,4 \\
\hline Miasto $<200$ tys. mieszkańców/Town $<200$ thousand inhabitants & 67 & 19,2 & 82 & 20,1 \\
\hline Miasto $<50$ tys. mieszkańców/Town $<50$ thousand inhabitants & 50 & 14,3 & 56 & 13,7 \\
\hline Miasto $<15$ tys. mieszkańców/Town $<15$ thousand inhabitants & 46 & 13,1 & 52 & 12,8 \\
\hline Wieś/osada wiejska/Village/rural settlement & 166 & 47,4 & 196 & 48,0 \\
\hline$(\mathrm{N})$ & 350 & 100,0 & 408 & 100,0 \\
\hline \multicolumn{5}{|c|}{ Aktywność zawodowa - poza studiowaniem/Professional activity beyond studies } \\
\hline Pracuję/l work & 207 & 59,2 & 186 & 45,6 \\
\hline $\begin{array}{l}\text { Nie pracuje, z powodu studiów dziennych/I don't work because of } \\
\text { my full-time studies }\end{array}$ & 97 & 27,7 & 190 & 46,6 \\
\hline Nie pracuję, nie mogę znaleźć pracy/I don't work, I can't find a job & 28 & 8.0 & 11 & 2.7 \\
\hline Inna odpowiedź/Other answer & 18 & 5,1 & 21 & 5,1 \\
\hline$(\mathrm{N})$ & 350 & 100,0 & 408 & 100,0 \\
\hline
\end{tabular}

Źródło: Dane za 2015 r. opracowanie na podstawie danych statystycznych [4, s. 24 i 25]. Dane za 2017 r. opracowanie własne.

Source: Data for 2015 based on statistical data [4, pp. 24 and 25]. Data for 2017 own study.

Odpowiedzi na tak postawione pytania mogą dać badania biur karier i śledzenie losów absolwentów kierunków związanych z bezpieczeństwem.

$Z$ doświadczenia autora wynikającego $z$ wieloletniej pracy w różnych podmiotach odpowiedzialnych za bezpieczeństwo wynika, że możliwości podejmowania pracy przez absolwentów kierunków związanych z bezpieczeństwem, w znacznym stopniu zależą nie tylko od ich wiedzy i umiejętności, ale od struktur poszczególnych komórek i jednostek organizacyjnych. Ostatnie lata pokazały, że uległo likwidacji wiele stanowisk pracy związanych z wykonywaniem zadań obronnych na wszystkich szczeblach podziału administracyjnego państwa oraz na szczeblu ministerialnym. Zlikwidowano departamenty, biura, wydziały, które merytorycznie odpowiadały za realizację ustawowych zadań w tym zakresie. Ustawa o zarządzaniu kryzysowym określiła system i mechanizmy działania systemu bezpieczeństwa, wskazała podmioty, jakie powinny funkcjonować na każdym jego szczeblu, ale nie wskazała minimalnych wymogów strukturalnych tych podmiotów. Wskutek tego w wielu centralnych instytucjach zadania obronne, zarządzania kryzysowego, czy też obrony cywilnej realizuje jedna lub dwie osoby (nie zawsze na pełnych etatach). Zdarza się też, że zadania te są im powierzane jako dodatkowe obowiązki. Osoby te włączane są w struktury różnych biur, których odpowiedzialność merytoryczna w żaden sposób nie odnosi się do zadań związanych z zapewnianiem bezpieczeństwa. Nagminne jest włączanie zadań szeroko rozumianego bezpieczeństwa do zadań dodatkowych pionu ochrony informacji niejawnych. Świadczy to niestety o kompletnym niezrozumieniu przez kierownictwo poszczególnych instytucji wagi tych zadań, a przecież na każdym szczeblu podziału administracyjnego państwa zadania zapewniania bezpieczeństwa należą do władzy administracyjnej i są ich zadaniami własnymi.

Przy tak tworzonym systemie stanowisk pracy związanych z zapewnianiem bezpieczeństwa osób, mienia i środowiska, wykonywania zadań obronnych oraz zarządzania kryzysowego, to od przygotowania najniższego szczebla systemu w dużej mierze
Responses to such questions may be provided by studying career offices and tracking the career paths of graduates of security-related programmes.

The author's long-standing experience in working at various bodies responsible for security demonstrated that the ability to find jobs by graduates of security-related studies largely depends not only on their knowledge and skills, but also on the structures of individual entities and organisational units. In recent years a large number of jobs connected with defence have been cut at all stages of the state's administrative division as well as at the ministerial level. Numerous departments, offices and divisions which were responsible for implementing statutory tasks in this field have been shut down. The Crisis Management Act defined the system and operational mechanisms of the security system, indicating the bodies that should operate at each level, but did not indicate the minimum structural requirements for such organs. As a result, in many central institutions, only one or two individuals are responsible for tasks related to defence, crisis management and civil defence (not always full-time). Sometimes these are only their additional responsibilities. Such individuals are part of the structure of various departments which are responsible for other fields and are completely unrelated to security. It is often the case that broadly understood security tasks are an additional responsibility of departments dealing with the protection of classified information. Unfortunately, this demonstrates a complete lack of understanding on the part of the management of those institutions of the importance of such tasks. After all, at every level of the state's administrative division, security tasks are entrusted to administrative authorities and are, in fact, part of their own tasks.

With such a system of jobs related to ensuring the security of people, property and the environment, and performing defence and crisis management tasks, it is the qualifications of the lowest levels of the system that largely determine the 
zależy jego skuteczność działania. Potwierdza to także generalna zasada reagowania na zdarzenia zagrażające ludziom, mieniu i środowisku, że rozpoczyna działanie ten podmiot, który pierwszy uzyskał informację o zdarzeniu. Zatem minimalizowanie struktur odpowiedzialnych za zapewnianie bezpieczeństwa na najniższych szczeblach, przy nieadekwatności posiadanych sił i środków na kolejnych poziomach systemu, jest co najmniej nieroztropnością organów władzy samorządowej i rządowej. Jednocześnie przekłada się to na ograniczone możliwości podejmowania pracy przez absolwentów kierunków związanych z bezpieczeństwem w miejscach swojego zamieszkania lub w najbliżej okolicy. Możliwość podjęcia pracy we własnym środowisku ma tę zaletę, że absolwent zna nie tylko okolicę, w której dorastał, ale często przeżył wiele sytuacji kryzysowych związanych z zagrożeniami naturalnymi. Zdaje sobie sprawę z ich zasięgu, oddziaływania na poszczególne rodzaje zabudowy, zna mieszkańców, zatem ułatwia mu to i skraca czas niezbędny do oceny sytuacji i podjęcia skutecznych działań mających na celu maksymalne ograniczenie zagrożenia lub eliminowanie skutków zdarzeń.

Znaczna część studiujących na kierunkach związanych z bezpieczeństwem, już na etapie studiów podejmuje działania zarobkowe. Nie zawsze są to prace w obszarach związanych z kierunkiem studiów, ale pozwalają im one zdobywać doświadczenie i umiejętności pracy zarówno samodzielnej, jak i zespołowej. W 2015 r. studiujący w trybie niestacjonarnym stanowili 51,4\% ogółu badanych, w czasie studiów pracowało o 9,8 p.p. więcej studiujących. Jednocześnie $8 \%$ nie pracowało z powodu trudności ze znalezieniem pracy. W 2017 r. wskaźniki te uległy bardzo istotnej zmianie. Przy $23,8 \%$ studiujących w trybie niestacjonarnym, pracowało $45,6 \%$ studiujących, a trudności ze znalezieniem pracy wskazało procentowo 2,96 razy mniej ankietowanych.

\section{Przyczyna podjęcia studiów na kierunkach związanych z bezpieczeństwem}

Podejmowanie decyzji o kierunku studiów wiąże się z przemyśleniami o przyszłej pracy potencjalnego studenta oraz wizją jego dorosłego życia. Młodzi ludzie często w bardzo ograniczonym stopniu biorą pod uwagę rzeczywiste możliwości jej podjęcia i bezkrytycznie podchodzą do swojego procesu studiowania. Zapominają, że dyplom uczelni wyższej nie przekłada się automatycznie na zapewnienie absolwentowi miejsca pracy zgodnego z kierunkiem ukończonych studiów.

Przykładowe porównanie wyników badań dotyczących przyczyny podjęcia studiów na kierunkach związanych z bezpieczeństwem w zależności od płci studiującego przedstawiają tabele 4.A. i 4.B.

Badania rekonesansowe i porównawcze niezmiennie wskazują, że ogółem ponad $83 \%$ studiujących na kierunkach związanych z bezpieczeństwem zakłada, że po zakończeniu studiów podejmie próbę podjęcia pracy bądź w służbach mundurowych, bądź w administracji publicznej na stanowiskach związanych z bezpieczeństwem (w 2015 r. 83,15\%, w 2017 r. 83,82\%).

W 2015 r. ponad $66 \%$ ogółu badanych studiujących wyrażało chęć pracy w służbach mundurowych, $z$ tego ponad połowę effectiveness of the whole structure. This is confirmed by the general rule of responding to events posing a threat to people, property and the environment, which states that the first unit to receive information about the event is the first to act. Therefore, reducing the structures responsible for security at the lowest levels, paired with the inadequacy of the available personnel and resources at higher levels, is at least an imprudence on the part of local and central authorities. This is reflected in reduced job opportunities for graduates of security-related programmes near their place of residence. The ability to take up work locally is advantageous, as the graduate not only knows the area in which he or she grew up, but might have also experienced a number of crisis events related to natural disasters occurring locally The graduate is aware of their area of influence and impact on specific types of buildings and structures and knows the residents, which facilitates and reduces time needed for assessing the situation and taking effective action aimed at mitigating danger or eliminating the results of incidents.

A large part of students of security-related programmes take up gainful employment during their studies. This employment is not always related to the field of study, but it allows students to gain experience and skills in working on their own and as part of teams. In 2015 part-time students comprised $51.4 \%$ of all respondents and 9.8 p.p. more respondents had jobs during their studies. At the same time, $8 \%$ did not work as they experienced difficulties finding a job. In 2017 these indicators changed significantly. Of $23.8 \%$ part-time students, $45.6 \%$ had jobs and 2.96 times fewer respondents said they experienced difficulties finding one.

\section{The reason for taking up security-related studies}

Choosing the field of study is related to thinking about a potential future job and one's outlook on adult life. Young people often pay very limited attention to the actual career prospects and lack a critical approach to the course of their studies. They tend to forget that a diploma of a higher education institution does not automatically pave the way to finding a job compatible with one's field of study.

Tables 4.A and 4.B show an example comparison of results concerning the reason for taking up security-related studies depending on the student's gender.

Preliminary and comparative studies invariably indicate that over $83 \%$ of students of security-related programmes assume that after graduation they will attempt to take up work in uniformed services or public administration in positions related to security $(83.15 \%$ in 2015 and $83.82 \%$ in 2017$)$.

In 2015 over $66 \%$ of all respondents expressed their plans to work in the uniformed services, of which more than half were women (4.57 p.p. more than men). If we consider only female students, then over $63 \%$ of them indicated their plans to find a job compatible with their field of study in the "uniformed services". 
stanowiły kobiety i było ich o 4,57 p.p. więcej niż mężczyzn. Jeżeli weźmiemy pod uwagę jedynie studiujące kobiety, to ponad $63 \%$ z nich wskazywało chęć podjęcia pracy zgodnie z kierunkiem studiów w "służbach mundurowych".

Jednocześnie było ich o 46,95 p.p. więcej niż wskazujących chęć podjęcia pracy zgodnie z kierunkiem studiów w "administracji publicznej", a zarazem o 42,86 p.p. więcej niż razem wziętych studentek, które jako główną przyczynę podjęcia studiów na kierunku związanym z bezpieczeństwem, wskazały chęć zdobycia kwalifikacji z zakresu bezpieczeństwa "bez związku z pracą" bądź wybrały „inną przyczynę" podjęcia studiów na tym kierunku.
This group was also 46.95 p.p. more numerous than the group of female students who declared their plans to find a job compatible with their field of study in "public administration," and 42.86 p.p. more numerous than all female students who indicated that they wanted to obtain qualifications in the field of security without any relation to work or chose another reason for taking up studies.

Tabela 4.A. Główna przyczyna podjęcia studiów na kierunku związanym z bezpieczeństwem - w zależności od płci studiującego - $2015 \mathrm{r}$. Table 4.A. The main reason for taking up studies in a field related to security - depending on the gender of the student - year 2015

\begin{tabular}{|c|c|c|c|c|c|c|}
\hline \multirow[b]{2}{*}{$\begin{array}{l}\text { Główna przyczyna podjęcia studiów na kierunku } \\
\text { związanym z bezpieczeństwem/The main reason } \\
\text { for taking up studies in a field related to security }\end{array}$} & \multicolumn{2}{|c|}{ Student/Male student } & \multicolumn{2}{|c|}{ Studentka/Female student } & \multicolumn{2}{|c|}{ Razem/Total } \\
\hline & $\begin{array}{l}\text { Liczba } \\
\text { badanych/ } \\
\text { Number } \\
\text { of respondents }\end{array}$ & $\begin{array}{l}\text { Wskaźnik } \\
\text { struktury } \\
\text { [w \%]/Stratum } \\
\text { weight [in \%] }\end{array}$ & $\begin{array}{l}\text { Liczba } \\
\text { badanych/ } \\
\text { Number } \\
\text { of respondents }\end{array}$ & $\begin{array}{l}\text { Wskaźnik } \\
\text { struktury } \\
\text { [w \%]/Stratum } \\
\text { weight [In \%] }\end{array}$ & $\begin{array}{l}\text { Liczba bada- } \\
\text { nych/Number } \\
\text { of respondents }\end{array}$ & $\begin{array}{l}\text { Wskaźnik } \\
\text { struktury } \\
\text { [w \%]/Stratum } \\
\text { weight [in \%] }\end{array}$ \\
\hline $\begin{array}{l}\text { chęć podjęcia pracy zgodnie z kierunkiem } \\
\text { studiów - w "służbach mundurowych"/intention } \\
\text { to work in accordance with the field of study - in } \\
\text { "uniformed services" }\end{array}$ & 108 & 70,13 & 124 & 63,27 & 232 & 66,29 \\
\hline $\begin{array}{l}\text { chęć podjęcia pracy zgodnie } z \text { kierunkiem studiów } \\
- \text { w administracji publicznej/intention to find } \\
\text { a job compatible with the field of study - in public } \\
\text { administration }\end{array}$ & 27 & 17,53 & 32 & 16,32 & 59 & 16,86 \\
\hline $\begin{array}{l}\text { chęć zdobycia kwalifikacji z zakresu } \\
\text { bezpieczeństwa - bez związku z pracą/willingness } \\
\text { to gain qualifications in the field of security - not } \\
\text { related to work }\end{array}$ & 14 & 9,09 & 28 & 14,29 & 42 & 12,00 \\
\hline Inna przyczyna/Other reason & 5 & 3,25 & 12 & 6,12 & 17 & 4,86 \\
\hline Razem/Total & 154 & 100,00 & 196 & 100,00 & 350 & 100,00 \\
\hline Analiza statystyczna/Statistical analysis & & $\begin{array}{l}\text { Chi-kwadrat Pears } \\
\text { 'earson's Chi squa }\end{array}$ & $\begin{array}{l}\text { ona: } 2.433245 ; d f \\
\text { re: } 2.433245 ; d f \text { (d }\end{array}$ & $\begin{array}{l}\text { stopnie swobody) } \\
\text { egrees of freedom }\end{array}$ & $\begin{array}{l}=3 ; p=0,487476 \\
=3 ; p=0.487476\end{array}$ & \\
\hline
\end{tabular}

Źródło: Opracowanie na podstawie danych statystycznych [3, s. 28].

Source: Study based on statistical data [3, p. 28].

Tabela 4.B. Główna przyczyna podjęcia studiów na kierunku związanym z bezpieczeństwem - w zależności od płci studiującego - $2017 \mathrm{r}$. Table 4.B. The main reason for taking up studies in a field related to security - depending on the gender of the student - year 2017

\begin{tabular}{|c|c|c|c|c|c|c|}
\hline \multirow{2}{*}{$\begin{array}{c}\text { Główna przyczyna podjęcia } \\
\text { studiów na kierunku związanym } \\
\text { z bezpieczeństwem/The main reason } \\
\text { for taking up studies in a field related } \\
\text { to security }\end{array}$} & \multicolumn{2}{|c|}{ Student/Male student } & \multicolumn{2}{|c|}{ Studentka/Female student } & \multicolumn{2}{|c|}{ Razem/Total } \\
\hline & $\begin{array}{l}\text { Liczba } \\
\text { badanych/ } \\
\text { Number of } \\
\text { respondents }\end{array}$ & $\begin{array}{c}\text { Wskaźnik } \\
\text { struktury [w \%]/ } \\
\text { Stratum weight } \\
\text { [in \%] }\end{array}$ & $\begin{array}{l}\text { Liczba } \\
\text { badanych/ } \\
\text { Number of } \\
\text { respondents }\end{array}$ & $\begin{array}{c}\text { Wskaźnik } \\
\text { struktury [w \%]/ } \\
\text { Stratum weight } \\
\text { [in \%] }\end{array}$ & $\begin{array}{l}\text { Liczba } \\
\text { badanych/ } \\
\text { Number of } \\
\text { respondents }\end{array}$ & $\begin{array}{c}\text { Wskaźnik } \\
\text { struktury [w \%]/ } \\
\text { Stratum weight } \\
\text { [in \%] }\end{array}$ \\
\hline $\begin{array}{l}\text { chęć podjęcia pracy zgodnie z kierunkiem } \\
\text { studiów - w "służbach mundurowych"/ } \\
\text { intention to work in accordance with the } \\
\text { field of study - in "uniformed services" }\end{array}$ & 129 & 61.72 & 134 & 67.34 & 263 & 64.46 \\
\hline $\begin{array}{l}\text { chęć podjęcia pracy zgodnie z kierunkiem } \\
\text { studiów - w administracji publicznej/ } \\
\text { intention to find a job compatible with the } \\
\text { field of study - in public administration }\end{array}$ & 37 & 17.70 & 42 & 21.11 & 79 & 19.36 \\
\hline $\begin{array}{l}\text { chęć zdobycia kwalifikacji z zakresu } \\
\text { bezpieczeństwa - bez związku z pracą/ } \\
\text { intention to gain qualifications in the field } \\
\text { of security - not related to work }\end{array}$ & 24 & 11.48 & 18 & 9.05 & 42 & 10.29 \\
\hline Inna przyczyna/Other reason & 19 & 9.09 & 5 & 2.51 & 24 & 5.88 \\
\hline Razem/Total & 209 & 100.00 & 199 & 100.00 & 408 & 100.00 \\
\hline Analiza statystyczna/Statistical analysis & & $\begin{array}{l}\text { Chi-kwadrat Pe } \\
\text { Pearson's Chi sc }\end{array}$ & $\begin{array}{l}\text { sona: } 9,195748 \\
\text { are: } 9.195748 ;\end{array}$ & $\begin{array}{l}\text { f(stopnie swobody) } \\
\text { (degrees of freedom }\end{array}$ & $\begin{array}{l}3 ; p=0,0268 \\
=3 ; p=0.0268\end{array}$ & \\
\hline
\end{tabular}

Źródło: Opracowanie własne.

Source: Own elaboration. 
Wyniki badań studentów wskazywały taki sam trend jak wśród studentek. Ponad $70 \% \mathrm{z}$ nich uznało chęć podjęcia pracy zgodnie z kierunkiem studiów w "służbach mundurowych" jako główną przyczynę podjęcia studiów na kierunku związanym z bezpieczeństwem. Jednocześnie było ich o 52,6 p.p. więcej zainteresowanych po studiach pracą w "administracji publicznej", a zarazem o 57,79 p.p. więcej niż razem wziętych studentów, którzy na pytanie dotyczące głównej przyczyny podjęci studiów na kierunku związanym z bezpieczeństwem, odpowiedzieli, że chcieli zdobyć kwalifikacje z zakresu bezpieczeństwa "bez związku z pracą" lub wybrali opcję „inna przyczyna".

Jednocześnie należy podkreślić, że procentowo studentów było więcej niż studentek, zarówno wśród chcących podjąć pracę zarówno w "służbach mundurowych", jak i w "administracji publicznej". Studentki przeważały nad studentami w grupach wskazujących jako główną przyczynę podjęcia studiów chęć zdobycia kwalifikacji z zakresu bezpieczeństwa "bez związku z pracą" (o 5,2 p.p.) oraz wśród wybierających „inną przyczynę" podjęcia studiów (o 2,87 p.p.).

W 2017 r. wyniki zmieniły się nieznacznie - o 1,83 p.p. zmniejszył się ogółem procentowy udział zainteresowanych podjęciem pracy w służbach mundurowych. Procentowo również przeważały kobiety i było ich ogółem o 1,22 p.p. więcej niż mężczyzn. W grupie badanych studentek było ich procentowo 3,2 razy więcej niż wskazujących chęć podjęcia pracy zgodnej z kierunkiem studiów w "administracji publicznej”, a zarazem 5,53 razy więcej niż łącznie studentek, które przy wyborze kierunku studiów kierowały się chęcią zdobycia kwalifikacji „bez związku z pracą” i wybierających „inną przyczynę" studiowania.

W 2017 r. w grupie badanych studentów w stosunku do 2015 r. nastąpił spadek o 8,41 p.p. zainteresowanych chęcią podjęcia pracy w "służbach mundurowych". Pomimo tego wskazujących chęć podjęcia pracy zgodnie z kierunkiem studiów w "służbach mundurowych" jako główną przyczynę podjęcia studiów na kierunku związanym z bezpieczeństwem było procentowo 3,49 razy więcej niż wskazujących chęć podjęcia pracy zgodnie z kierunkiem studiów $\mathrm{w}_{\text {„ }}$ administracji publicznej", a zarazem 3 razy więcej niż łącznie studentów, którzy przy wyborze kierunku studiów, kierowali się chęcią zdobycia kwalifikacji „bez związku z pracą" i wybierających „inną przyczynę" studiowania.

Podobne zainteresowanie przeszłą pracą w sferze budżetowej (w służbach mundurowych, bądź w administracji na stanowiskach związanych z bezpieczeństwem) wyrażało w:

- 2015 r. - 87,66\% studiujących w trybie stacjonarnym i 79,59\% studiujących w trybie niestacjonarnym;

- 2017 r. - odpowiednio 85,21\% i 79,38\% studiujących.

Przykładowe zestawienie wyników uzyskanych w badaniach rekonesansowych w 2015 i porównawczych w 2017 r. zakresie wskazania głównej przyczyny podjęcia studiów na kierunku związanym z bezpieczeństwem w zależności od trybu studiowania przedstawiają tabele 5.A. i 5.B.
Studies among male students showed the same trend as those among female students. More than $70 \%$ declared their willingness to find a job compatible with their field of study in the "uniformed services" as the main reason for studying a security-related programme. This group was also 52.6 p.p. more numerous than the group of male students who declared their plans to find a job in "public administration," and 57.79 p.p. more numerous than all male students who indicated that they wanted to obtain qualifications in the field of security "unrelated to work" or chose "another reason" for taking up studies.

At the same time, it should be emphasised that the percentage of male students was higher than that of female students, both among those who planned a job in "uniformed services" and among those who intended to work in "public administration" More female students than male students indicated the intention to obtain qualifications in the field of security "unrelated to work" (by 5.2 p.p.) and chose "other reason" of taking up studies (by 2.87 p.p.).

In 2017 the results changed only slightly - the total percentage share of students interested in taking up work in the uniformed services dropped by 1.83 p.p. The percentage share of women was also higher and there were 1.22 p.p. more of them than men. In the group of female respondents, a 3.2 times higher percentage declared their intention to find a job compatible with their field of study in "public administration" and also 5.53 times higher than the total percentage of female students who wanted to obtain qualifications "unrelated to work" and chose "other reason" of taking up studies.

In 2017 the there was an 8.41 p.p. decrease in the number of people interested in finding a job in "uniformed services" in relation to 2015. Despite this, the percentage of respondents who indicated their intention to find a job compatible with their field of study in "uniformed services" as the main reason for taking up studies in a security-related field was 3.49 times higher than those who indicated their intention to find a job compatible with their field of study in "public administration" and 3 times more than the total percentage of students who wanted to obtain qualifications "unrelated to work" and chose "another reason" of taking up studies.

A similar interest in future work in the public sector (in uniformed services and administration at positions connected with security) was expressed in

- 2015 - by $87.66 \%$ full-time students and $79.59 \%$ of part-time students;

- 2017 - by $85.21 \%$ and $79.38 \%$ of students, respectively.

Tables 5.A and 5.B show an example comparison of results obtained in preliminary studies in 2015 and in comparative studies in 2017 in terms of indicating the main reason for taking up studies in a security-related field depending on the mode of study. 
Tabela 5.A. Główna przyczyna podjęcia studiów na kierunku związanym z bezpieczeństwem - w zależności w zależności od trybu studiowania - 2015 r. Table 5.A. The main reason for taking up studies in a field related to security - depending on the study mode - year 2015

\begin{tabular}{|c|c|c|c|c|c|c|}
\hline \multirow[b]{2}{*}{$\begin{array}{c}\text { Główna przyczyna podjęcia studiów na } \\
\text { kierunku związanym z bezpieczeństwem/ } \\
\text { The main reason for taking up studies in } \\
\text { a field related to security }\end{array}$} & \multicolumn{2}{|c|}{ Stacjonarne Full-time study } & \multicolumn{2}{|c|}{ Niestacjonarne/Part-time study } & \multicolumn{2}{|c|}{ Razem Total } \\
\hline & $\begin{array}{l}\text { Liczba } \\
\text { badanych/ } \\
\text { Number of } \\
\text { respondents }\end{array}$ & $\begin{array}{l}\text { Wskaźnik } \\
\text { struktury [w \%]/ } \\
\text { Stratum weight } \\
\text { [in \%] }\end{array}$ & $\begin{array}{l}\text { Liczba } \\
\text { badanych/ } \\
\text { Number of } \\
\text { respondents }\end{array}$ & $\begin{array}{l}\text { Wskaźnik } \\
\text { struktury [w \%]/ } \\
\text { Stratum weight } \\
\text { [in \%] } \\
\end{array}$ & $\begin{array}{l}\text { Liczba bada- } \\
\text { nych/Number } \\
\text { of respondents }\end{array}$ & $\begin{array}{c}\text { Wskaźnik } \\
\text { struktury [w \%]/ } \\
\text { Stratum weight } \\
\text { [in \%] } \\
\end{array}$ \\
\hline $\begin{array}{l}\text { chęć podjęcia pracy zgodnie z kierunkiem } \\
\text { studiów - w "służbach mundurowych"/intention } \\
\text { to work in accordance with the field of study - in } \\
\text { "uniformed services" }\end{array}$ & 117 & 75.97 & 115 & 58.67 & 232 & 66.29 \\
\hline $\begin{array}{l}\text { chęć podjęcia pracy zgodnie z kierunkiem } \\
\text { studiów - w administracji publicznej/intention to } \\
\text { find a job compatible with the field of study - in } \\
\text { public administration }\end{array}$ & 18 & 11.69 & 41 & 20.92 & 59 & 16.86 \\
\hline $\begin{array}{l}\text { chęć zdobycia kwalifikacji z zakresu } \\
\text { bezpieczeństwa - bez związku z pracą/intention } \\
\text { to gain qualifications in the field of security } \\
\text { - unrelated to work }\end{array}$ & 12 & 7.79 & 30 & 15.31 & 42 & 12.00 \\
\hline Inna przyczyna/Other reason & 7 & 4.55 & 10 & 5.10 & 17 & 4.86 \\
\hline Razem/Total & 154 & 100.00 & 196 & 100.00 & 350 & 100.00 \\
\hline Analiza statystyczna/Statistical analysis & & $\begin{array}{l}\text { Chi-kwadrat Pear } \\
\text { Pearson's Chi squ }\end{array}$ & $\begin{array}{l}\text { sona: } 7,312082 ; \\
\text { are: } 7.312082 ; \mathrm{df}\end{array}$ & $\begin{array}{l}\text { (stopnie swobody) } \\
\text { legrees of freedom) }\end{array}$ & $\begin{array}{l}=3 ; p=0,062599 \\
=3 ; p=0.062599\end{array}$ & \\
\hline
\end{tabular}

Źródło: Opracowanie na podstawie danych statystycznych [3, s. 29].

Source: Study based on statistical data [3, p. 29].

Wyniki badań rekonesansowych wykazały, że jedynie $1 / 4$ studiujących w trybie stacjonarnym nie wyrażała chęci podjęcia pracy zgodnie z kierunkiem studiów w "służbach mundurowych". W badaniach porównawczych było to już ponad $1 / 3$ studiujących w trybie stacjonarnym. Wśród studiujących w trybie niestacjonarnym w 2015 r. ponad $2 / 5$ studiujących nie łączyło studiowania na kierunkach związanych z bezpieczeństwem z chęcią podjęcia pracy zgodnie z kierunkiem studiów w "służbach mundurowych". Badania porównawcze w 2017 r. wykazały, że procentowo zmniejsza się grupa tak odpowiadających. Było ich bowiem nieco ponad $1 / 3$ ogółu badanych.
The preliminary study results demonstrated that only $1 / 4$ fulltime students were not willing to take up work compatible with their field of study in "uniformed services." In the comparative study, this proportion increased to more than $1 / 3 . \ln 2015$ over $^{2} / 5$ part-time students did not think of the pursued security-related programme in the context of finding a job compatible with their field of study in "uniformed services." The comparative study performed in 2017 demonstrated that this group of respondents is decreasing in percentage. They accounted for slightly more than $1 /{ }_{3}$ of all respondents.

Tabela 5.B. Określenie głównej przyczyny podjęcia studiów na kierunku związanym z bezpieczeństwem - w zależności w zależności od trybu studiowania - $2017 \mathrm{r}$.

Table 5.B. Determination of the main reason for taking up studies in a field related to security - depending on the study mode - year 2017

\begin{tabular}{|c|c|c|c|c|c|c|}
\hline \multirow[b]{2}{*}{$\begin{array}{c}\text { Główna przyczyna podjęcia studiów na } \\
\text { kierunku związanym z bezpieczeństwem/ } \\
\text { The main reason for taking up studies in } \\
\text { a field related to security }\end{array}$} & \multicolumn{2}{|c|}{ Stacjonarne/Full-time study } & \multicolumn{2}{|c|}{ Niestacjonarne/Part-time study } & \multicolumn{2}{|c|}{ Razem/Total } \\
\hline & $\begin{array}{l}\text { Liczba badanych/ } \\
\text { Number of } \\
\text { respondents }\end{array}$ & $\begin{array}{l}\text { Wskaźnik } \\
\text { struktury [w \%]/ } \\
\text { Stratum weight } \\
\text { [in \%] }\end{array}$ & $\begin{array}{l}\text { Liczba badanych/ } \\
\text { Number of } \\
\text { respondents }\end{array}$ & $\begin{array}{l}\text { Wskaźnik } \\
\text { struktury [w \%]/ } \\
\text { Stratum weight } \\
\quad \text { [in \%] }\end{array}$ & $\begin{array}{l}\text { Liczba badanych/ } \\
\text { Number of } \\
\text { respondents }\end{array}$ & $\begin{array}{l}\text { Wskaźnik } \\
\text { struktury [w \%]/ } \\
\text { Stratum weight } \\
\text { [in \%] }\end{array}$ \\
\hline $\begin{array}{l}\text { chęć podjęcia pracy zgodnie z kierunkiem } \\
\text { studiów - w "służbach mundurowych"/intention } \\
\text { to work in accordance with the field of study - in } \\
\text { "uniformed services" }\end{array}$ & 117 & 75,97 & 115 & 58,67 & 232 & 66,29 \\
\hline $\begin{array}{l}\text { chęć podjęcia pracy zgodnie } z \text { kierunkiem } \\
\text { studiów - } w \text { administracji publicznej/intention to } \\
\text { find a job compatible with the field of study - in } \\
\text { public administration }\end{array}$ & 18 & 11,69 & 41 & 20,92 & 59 & 16,86 \\
\hline $\begin{array}{l}\text { chęć zdobycia kwalifikacji z zakresu } \\
\text { bezpieczeństwa - bez związku z pracą/intention } \\
\text { to gain qualifications in the field of security } \\
\text { - unrelated to work }\end{array}$ & 12 & 7,79 & 30 & 15,31 & 42 & 12,00 \\
\hline Inna przyczyna/Other reason & 7 & 4.55 & 10 & 5,10 & 17 & 4,86 \\
\hline Razem/Total & 154 & 100,00 & 196 & 100,00 & 350 & 100,00 \\
\hline Analiza statystyczna/Statistical analysis & & $\begin{array}{l}\text { Chi-kwadrat Pears } \\
\text { Pearson's Chi squa }\end{array}$ & $\begin{array}{l}\text { rsona: } 7,312082 ; \mathrm{df} \\
\text { lare: } 7.312082 ; \mathrm{df}(\mathrm{d}\end{array}$ & $\begin{array}{l}\text { (stopnie swobody) } \\
\text { degrees of freedom) }\end{array}$ & $\begin{array}{l}\text { ) }=3 ; p=0,062599 \\
\text { h) }=3 ; p=0.062599\end{array}$ & \\
\hline
\end{tabular}

Źródło: Opracowanie własne.

Source: Own elaboration. 
Jednocześnie podkreślić należy, że badania porównawcze w stosunku do badań rekonesansowych wykazały wśród studiujących $w$ trybie stacjonarnym wzrost zainteresowania pracą zgodną z kierunkiem studiów w "administracji publicznej" o 9,53 p.p. do poziomu $21,22 \%$. W ciągu trzech lat nastąpił więc $81,5 \%$ wzrost odpowiadających w ten sposób na pytanie o główną przyczynę podjęcia studiów na kierunku związanym z bezpieczeństwem.

Wśród studiujących w trybie niestacjonarnym nastąpił spadek o 7,52 p.p. uznających za główną przyczynę podjęcia studiów na kierunku związanym z bezpieczeństwem chęć podjęcia pracy zgodnie z kierunkiem studiów w „administracji publicznej". W ciągu trzech lat nastąpił $36 \%$ spadek udzielających takiej odpowiedzi. Jednocześnie procentowo studiujących w trybie niestacjonarnym, którzy wykazywali chęć podjęcia pracy zgodnej z kierunkiem studiów w "administracji publicznej, było o 1,03 p.p. mniej niż tych, którzy kierowali się chęcią zdobycia kwalifikacji „bez związku z pracą”.

Zarówno w 2015 r., jak i w 2017 r. utrzymywał się niski wskaźnik tych, którzy w odpowiedzi na pytanie o główną przyczynę podjęcia studiów na kierunku związanym z bezpieczeństwem wybrali opcję „inna przyczyna". W 2015 roku było to ok. 5\% badanych w obu trybach studiów. Studiujących w trybie niestacjonarnym, którzy udzielili takiej odpowiedzi, było o 0,55 p.p. więcej niż studiujących w trybie stacjonarnym. W 2017 r. w obu trybach było to ok. $6 \%$ badanych. Studiujących w trybie niestacjonarnym było o 0,4 p.p. więcej niż studiujących w trybie stacjonarnym.

Podkreślić należy, że w 2017 r. w stosunku do 2015 r. zmieniły się, w zależności od trybu studiowania, procentowe udziały w zakresie głównej przyczyny podejmowania studiów. W 2017 r. studiujących w trybie niestacjonarnym, którzy wskazywali chęć podjęcia pracy zgodnie z kierunkiem studiów w "służbach mundurowych", było procentowo więcej niż studiujących w trybie stacjonarnym o 1,99 p.p. W 2015 r. przeważali o 17,3 p.p. studiujący trybie stacjonarnym. Odwrotnie było wśród uznających za główną przyczynę podjęcia studiów chęć podjęcia pracy zgodnie z kierunkiem studiów w „administracji publicznej”. W 2015 r. studiujących w trybie stacjonarnym, którzy wybrali taką odpowiedź było o 9,23 p.p. mniej niż wśród studiujących w trybie niestacjonarnym. W 2017 r. natomiast studiujących w trybie stacjonarnym, którzy udzielili takiej odpowiedzi było o 7,82 p.p. więcej niż wśród studiujących w trybie niestacjonarnym.

\section{Czas przeznaczany na naukę dziennie przez studiujących na kierunkach związanych z bezpieczeństwem}

Z punktu widzenia potencjalnych pracodawców istotne są informacje dotyczące, wiedzy, kompetencji i umiejętności, jakich nabywa studiujący na kierunkach związanych z bezpieczeństwem. Pewnym miernikiem rzetelności podejścia do studiowania i oceny, czy absolwent, jest dobrym kandydatem do pracy i posiada rzeczywistą oraz ugruntowaną wiedzę jest czas przeznaczany dziennie przez studiujących na naukę samodzielną . Zmienną tę badano w zależności od: płci studiujących, roku studiów, trybu
It should also be emphasised that there was an increase in interest among full-time students in finding a job compatible with their field of study in "public administration" from 9.53 p.p. in preliminary studies to $21.22 \%$ in comparative studies. This means that over a span of three years there was an $81.5 \%$ increase in respondents who provided this answer to the question about the main reason of taking up security-related studies.

Among part-time students, there was a 7.52 p.p. decrease in respondents who indicated their intention to find a job compatible with their field of study in "public administration" as the main reason of taking up security-related studies. The number of respondents providing this answer decreased by $36 \%$ after three years. At the same time, the percentage of part-time students who indicated their intention to find a job compatible with their field of study in "public administration" was 1.03 p.p. lower than of those who wanted to obtain qualifications "unrelated to work."

Both in 2015 and in 2017 there was a low percentage of those who indicated "other reason" as the main reason for taking up studies in a security-related field. In 2015 it was about $5 \%$ of respondents in both modes of study. This answer was given by 0.55 p.p. more part-time students than full-time students. In 2017 for both modes of study this percentage amounted to about $6 \%$ of respondents. This answer was given by 0.4 p.p. more part-time students than full-time students.

It should be stressed that in 2017, in relation to 2015, there were changes in the percentage shares of responses to the question about the main reason of taking up studies, depending on the mode of study. In 2017 the percentage of respondents who indicated their intention to find a job compatible with their field of study in "uniformed services" was 1.99 p.p. higher among part-time students than among full-time students. In 2015 there were 17.3 p.p. more full-time students who gave this response. The opposite was true for respondents who indicated the intention to find a job compatible with their field of study in "public administration" as the main reason of taking up studies. In 2015 there were 9.23 p.p. fewer full-time students who gave this response than part-time students. In 2017 this answer was given by 7.82 p.p. more full-time students than part-time students.

\section{Daily time spent on self-study by students of security-related programmes}

Potential employers are interested in information regarding the knowledge, competences and skills acquired by students in security-related programmes. A certain measure of a student's reliability in terms of approach to studying, and a way of assessing whether the graduate is a good candidate and has actual and well-established knowledge, is the time spent daily on self-study. This variable was studied as divided by gender, year of study, mode of study, age, marital status, number of children, programme and employment. Table 6 shows 
studiowania, wieku studiującego, stanu cywilnego, liczby posiadanych dzieci, kierunku studiów, zatrudnienia studiującego. Zestawienie odpowiedzi ogółem w zakresie czasu przeznaczanego przez studiujących na naukę własną dziennie przedstawia tabela 6 . a comparison of the answers regarding the daily time spent by students on self-study.

Tabela 6. Czas przeznaczany na naukę własną dziennie - badania rekonesansowe i porównawcze - liczba odpowiedzi Table 6. Daily time spent on self-study - preliminary and comparative studies - number of answers

\begin{tabular}{lcc}
\hline \multicolumn{1}{c}{$\begin{array}{c}\text { Czas przeznaczany na naukę własną - dziennie/ } \\
\text { Time spent on self-study - daily }\end{array}$} & \multicolumn{2}{c}{ Liczba odpowiedzi (i procent)/Number of answers (and percent) } \\
\cline { 2 - 3 } Ponad 4 godz./More than 4 hours & $\mathbf{2 0 1 5}$ r./Year 2015 & $\mathbf{2 0 1 7}$ r./Year 2017 \\
\hline Ponad 2 godz./More than 2 hours & $10(2,86 \%)$ & $12(2,94 \%)$ \\
\hline Do 2 godz./Up to two hours & $49(14,00 \%)$ & $229(56,13 \%)$ \\
\hline Inny wymiar czasu/None of the above & $170(48,57)$ & $114(27,94 \%)$ \\
\hline$N$ & $121(34,57)$ & $408(100 \%)$ \\
\hline
\end{tabular}

Źródło: Dane za 2015 r. opracowanie na podstawie danych statystycznych [3, s. 61]. Dane za 2017 r. opracowanie własne. Source: Data for 2015, study based on statistical data [3, p. 61]. Data for 2017 own elaboration.

Uzyskane w obu edycjach badań wyniki nie napawają zbytnim optymizmem. Mniej niż $3 \%$ ogółu badanych przeznacza na naukę własną dziennie ponad 4 godziny, a co 7 badany uczy się ponad 2 godziny dziennie. Niepokojący jest fakt, że w 2015 r. prawie co trzeci, a w 2017 r. prawie co czwarty badany, wybrał opcję „inny wymiar czasu”. Przy kategorii "do dwóch godzin”, którą w 2015 r. wybrał prawie do drugi studiujący, a w 2017 r. wskaźnik ten zwiększył się do $56,13 \%$, oznacza to, że ok. $30 \%$ studiujących całkowicie lekceważy codzienną naukę i nie uczy się wcale.

Analiza wyników badań czasu przeznaczanego na naukę w zależności od roku studiów wskazuje, że w badaniach rekonesansowych na II roku studiów nie było ani jednej osoby, która przeznaczałaby na naukę własną ponad 4 godziny dziennie. $\mathrm{Na}$ I roku studiów było 5,51\% takich studentów, a na III roku 2,03\%. Ponad 2 godziny dziennie na naukę własną przeznaczało najwięcej studiujących na I roku studiów - 15,75\% i było ich o 1,08 p.p. więcej niż studiujących na II roku oraz o 3,59 p.p. więcej niż studiujących na III roku. Najliczniejszą procentowo grupę stanowili przeznaczający na naukę własną do dwóch godzin dziennie. Najwięcej ich było na II roku studiów $56 \%$ i było ich o 7,18 p.p. więcej niż na I roku i o 11,41 p.p. więcej niż na III roku.

Badania rekonesansowe wskazały niepokojący fakt, że $34,57 \%$ studiujących wybrało "inną odpowiedź" - zatem nie mieścili się w kategorii przeznaczających na naukę własną do dwóch godzin. Najwięcej ich było na III roku studiów - 41,22\%. $\mathrm{Na}$ I i Il roku odsetek tak odpowiadających wynosił ponad $29 \%$.

Badania porównawcze potwierdziły negatywne statystyki dotyczące studiujących:

- którzy wybrali opcję „inną odpowiedź" - ponad $27 \%$ ogółu studiujących nie przeznacza na naukę nawet dwóch godzin dziennie;

- na Il roku studiów - ponownie okazało się, że studenci II rocznika przeznaczają najmniej czasu na naukę własną dziennie, aczkolwiek ok. $3 \%$ z nich przeznaczało na naukę własną ponad 4 godziny dziennie. Na I roku odsetek tak odpowiadających zmniejszył się prawie dwukrotnie i wyniósł jedynie 2,83\%. Na III roku studiów procentowy udział studiujących, którzy przeznaczali na naukę własną
The results of both studies are far from optimistic. Less than $3 \%$ of all respondents spend more than 4 hours on self-study and only one in seven studies more than 2 hours a day. It is disturbing that in 2015 nearly one in three and in 2017 nearly one in four respondents chose the answer "none of the above". With the category "up to two hours," which in 2015 was chosen by nearly a half of all respondents and in 2017 by $56.13 \%$ it means that about $30 \%$ of students completely ignore the need for daily self-study and choose not to study at all.

An analysis of the responses on self-study time by year of study shows that in the preliminary study there were no second-year students who said they spent over 4 hours a day on self-study. This was only $5.51 \%$ for first-year students and $2.03 \%$ for third-year students. Among the students who spent more than 2 hours a day on self-study, the most numerous group were first-year students $-15.75 \%$ (1.08 p.p. more than second-year students and 3.59 p.p. more than third-year students). The largest percentage of respondents spent up to two hours on daily self-study. Here, the most numerous group were second-year students $-56 \%$ (7.18 p.p. more than first-year students and 11.41 p.p. more than third-year students).

Preliminary studies demonstrated the disturbing fact that $34.57 \%$ of students chose "other answer," which meant that they did not fit in the category of spending up to two hours on selfstudy. The highest percentage was among third-year students $-41.22 \%$. For first- and second-year students it was over $29 \%$.

Comparative studies confirmed the poor statistics in this respect among students who:

- chose "other answer" - over $27 \%$ of all students did not spend as little as two hours a day on self-study;

- the results among second-year students once again demonstrated that they spend the smallest amount of time on daily self-study, although $3 \%$ spent more than 4 hours a day. Among first-year students the percentage of respondents providing this answer decreased almost twofold to only $2.83 \%$. Among third-year students the percentage of students who spent over 4 hours a day on self-study increased to $3.66 \%$. Clearly, it is 
ponad 4 godziny dziennie zwiększył się do 3,66\%. Trudno zatem o jakiekolwiek pozytywne wnioski w tej sprawie.

Podobnie jak w 2015 r. również w 2017 r. największą grupę na wszystkich rocznikach studiów stanowili studiujący, którzy przeznaczali na naukę własną do dwóch godzin dziennie. Ogółem było ich $56,13 \%$, w stosunku do badań rekonesansowych jest to o $7,56 \%$ więcej. W grupie tej dominowali studiujący III rocznika $57,32 \%$. Na II roku było ich $54,35 \%$, a na I roku $56,6 \%$.

Zmniejszył się natomiast ogółem procentowy udział studiujących przeznaczających na naukę ponad 2 godziny dziennie z $14 \%$ do $12,99 \%$. W poszczególnych rocznikach było to: I rok - 14,55\%, II rok - 15,94\%, III rok - 9,76\%.

Przeznaczanie na naukę własną tak małej liczby godzin może świadczyć o bardzo niepokojącym zjawisku, głębokiej „pauperyzacji” studiowania na kierunkach związanych z bezpieczeństwem.

\section{Wnioski}

W artykule przedstawiono szczegółowe wnioski odnoszące się do poszczególnych wyników badań rekonesansowych i porównawczych. Warto także zwrócić uwagę na szerszy aspekt prezentowanych analiz i wpływ uzyskanych wyników na przygotowanie społeczeństwa na negatywne zdarzenia, a także na skuteczność realizacji zadań przez instytucje odpowiedzialne za zapewnianie bezpieczeństwa, które poszukują pracowników wśród absolwentów kierunków związanych z bezpieczeństwem.

Przytoczone odpowiedzi na sześć z dwudziestu pięciu pytań ankietowych zadanych studentom wykazały, że istnieje potrzeba prowadzenia analiz w zakresie poznawania motywacji podejmowania studiów na kierunkach związanych z bezpieczeństwem. Pozwalają one uczelniom na rozszerzanie wiedzy o potencjalnym kandydacie na studia, a pracodawcom dają informację, z jakim absolwentem będą mieli oni do czynienia.

Chociaż w zdecydowanej większości studiujący kierowali się przy wyborze studiów chęcią podjęcia pracy zgodnie z kierunkiem ( $w$ służbach mundurowych lub $w$ administracji publicznej na stanowiskach związanych z bezpieczeństwem), to pojawia się wątpliwość, czy z uwagi na czas poświęcany przez nich na naukę własną, potencjalny pracodawca otrzyma dobrze przygotowanego kandydata do pracy.

Jeżeli ten istotny w procesie zapewniania bezpieczeństwa czynnik ludzki nie będzie najmocniejszym ogniwem i będzie zawodził, to bez względu na szczebel systemu, w którym będzie on wykonywał swoje zadania, nie będziemy mogli powiedzieć, że tworzy on wartość dodaną i jest gwarantem skutecznego funkcjonowania mechanizmów i systemów bezpieczeństwa państwa i obywateli.

Uzyskane w zakresie przeznaczania na naukę własną czasu odpowiedzi i wyniki badań skłaniają do zadania kilka pytań: Jak można ukończyć studia, przeznaczając na naukę minimalne ilości czasu lub nie ucząc się wcale? Czy istnieje grupa wykładowców, którzy zaliczają poszczególne przedmioty, nawet jeśli student nie posiada minimalnej wiedzy? Czy taka jest polityka władz uczelni - za wszelką cenę utrzymać studiującego difficult to draw any positive conclusions from these results.

As in 2015, in 2017 the largest group in all years of study comprised those students who spent up to two hours a day on self-study. The total number of such respondents was $56.13 \%$, which was $7.56 \%$ more than in the preliminary study. This group was dominated by third-year students $(57.32 \%)$. This percentage was $54.35 \%$ among second-year students and $56.6 \%$ among first-year students.

Also, the total percentage of students spending more than 2 hours a day on self-study decreased from $14 \%$ to $12.99 \%$. For respective years of study this amounted to: Year $1-14.55 \%$, Year $2-15.94 \%$, Year $3-9.76 \%$.

Spending so little time on self-study might be a sign of a highly disturbing phenomenon - the advanced "pauperisation" of studying security-related fields.

\section{Conclusions}

The article presents detailed conclusions on the specific results of the preliminary and comparative studies. We should also recognise the wider context of the presented analyses and impact of the obtained results on preparing society to adverse events, as well as on the effectiveness of performing tasks by institutions responsible for ensuring security which look for employees among people graduating from security-related programmes.

The quoted answers to six of the twenty questions presented to students demonstrated that there is a need for studying the motivations of students who take up security-related studies. They enable higher education institutions to expand their knowledge about potential candidates and provide employees with information about graduates.

Although the vast majority of students chose their studies because they wanted to find a job compatible with the field of study (in uniformed services or public administration in positions related to security), there is reason to doubt as to whether, due to the short self-study time, the prospective employer will find well-prepared candidates.

If this human factor, which is significant in the process of ensuring security, fails to be the strongest link, then, regardless of the level of the system, we would not be able to say that it adds value and guarantees the effective functioning of state- and citizen-protection security mechanisms and systems.

The responses and study results obtained for self-study time lead to several questions. How can you complete your studies spending only a minimal amount of time on study or not studying at all? Is there a group of teachers who let their students pass even if they lack the basic knowledge? Is this the policy of higher education institution authorities - to make students stay at all costs so that they take up second-cycle studies there? Both situations are highly disadvantageous to the potential employer and to the reputation of the higher education institution. If such situations exist, they are a short-sighted policy on the part of both the authorities and academics. 
i najlepiej, aby po studiach I stopnia rozpoczął na tej samej uczelni studia II stopnia? Oba te przypadki są bardzo niekorzystne dla potencjalnego pracodawcy oraz dla opinii, jaka wytwarza się na temat uczelni. Jeżeli takie zjawiska istnieją, to są one wielką krótkowzrocznością zarówno władz uczelni, jak i zatrudnianych przez nich pracowników naukowych. Może to powodować, że struktury wielu instytucji funkcjonujących w podsystemach zapewniania bezpieczeństwa państwa i obywateli, na poszczególnych szczeblach podziału administracyjnego państwa, nie otrzymają dobrze przygotowanego kandydata do pracy [por. 6]. Społeczeństwo będzie niewystarczająco przygotowane do zmierzenia się z sytuacjami kryzysowymi.

Wyniki badań wskazują, że poszczególne uczelnie prowadzące studia na kierunkach związanych z bezpieczeństwem nie mogą optymistycznie zakładać, że w procesie rekrutacji pozyskają oprócz bieżących absolwentów szkół średnich [stanowiących obecnie już ponad $89 \%$ rozpoczynających studia w tym samym roku (75\%) lub rok po maturze (14\%)], także osoby starsze, które z różnych powodów nie kontynuowały nauki po ukończeniu szkoły średniej. Stanowią oni jedynie nieco ponad $10 \%$ studiujących.

Liczność uczelni prowadzących kierunki studiów związanych z bezpieczeństwem spowodowała, że w zasadzie wyczerpał się zasób absolwentów szkół średnich, którzy podejmowali studia na dowolnym kierunku, w tym również na kierunkach związanych z bezpieczeństwem, tylko po to aby uzyskać dyplom ukończenia studiów wyższych, jako niezbędny element obejmowania kolejnych wyższych stanowisk w strukturze zatrudniających ich instytucji. Uczelnie, które będą chciały kontynuować nauczanie na kierunkach związanych z bezpieczeństwem oraz będą opierać na nich swoje funckjonowanie, będą miały do wyboru tylko dwa rozwiązania. Pierwszym z nich jest podniesienie jakości studiów i zwiększenie wymagań, które z jednej strony przełożą się na konieczność konkurowania z innymi uczelniami o dobrego absolwenta szkoły średniej i usuwania z uczelni studentów, którzy nie osiągają zadowalających wyników w nauce. Wtedy absolwenci studiów będą kandydatami spełniającymi oczekiwania potencjalnych pracodawców. Drugim rozwiązaniem jest maksymalne obniżenie jakości studiów i wymagań, aby wśród uczelni nie mieć konkurentów w pozyskiwaniu przyszłych studentów, którzy nie zostaliby przyjęci na inne kierunki studiów.

Zmiana jakości w ilość być może umożliwiłaby finansowe przetrwanie poszczególnych uczelni, jednakże nie gwarantowała potencjalnym pracodawcom, nawet w ograniczonym stopniu, pozyskania wartościowego kandydata do pracy. Absolwenci tych uczelni zasilaliby grono osób, które nie mogą znaleźć pracy i tych, którzy w rozmowach z pracodawcą wskazują w odpowiedziach na pytanie o umiejętności i kwalifikacje, że mają wyższe wyksztalcenie. Kierujący uczelniami muszą jednak brać pod uwagę chociażby wyniki Diagnozy społecznej 2015, która jednoznacznie wskazuje, że "[w] ostatnich dwóch latach spadła stopa zwrotu ze wszystkich poziomów studiów po szkole średniej. Dyplomy doktora i magistra zachowały mimo spadku swoje finansowe znaczenie, ale licencjat przestał być praktycznie opłacalną inwestycją" [7, s. 238].
This could lead to a situation where the institutions making up the state's security system at various stages of the state's administrative division, will have problems finding well-prepared candidates [cf. 6]. The public will not be sufficiently prepared to face crises.

The study results demonstrated that higher education institutions offering security-related programmes should not optimistically assume that, in addition to recent secondary school leavers [who currently comprise more than $89 \%$ of those taking up studies - in the same year (75\%) or one year after their secondary school leaving exam (14\%)], they will also attract candidates who, for various reasons did not continue their education after leaving secondary school. This group comprises only slightly over $10 \%$ of students.

The high number of higher education institutions introducing security-related programmes resulted in the almost complete unavailability of the population of secondary school leavers who were ready to take up studies in any field, including those related to security, only to obtain a higher school diploma as a necessity to be considered for promotion at the institutions employing them. Those higher education institutions which intend to continue teaching security-related subjects and rely on them for their functioning, will have only two solutions to choose from. The first is to improve the quality of studies and introduce more stringent requirements, which will force them, on the one hand, to compete with other higher education institutions to attract better-performing secondary school leavers and, on the other, to exclude underperforming students. If this solution is adopted then graduates will meet the expectations of their prospective employers. The second solution is to reduce the quality of studies and requirements to an extremely low level, so that there would be no competition with other higher education institutions in attracting students who would stand no chance of being admitted to other programmes.

Replacing quality with quantity might enable some higher education institutions to survive in financial terms, but potential employees will be left without even limited prospects of finding valuable candidates for jobs. People who graduated from those higher education institutions would join the numbers of those who experience difficulties finding jobs and indicate higher education in interviews with their potential employers. However, managers of higher education institutions should take into account the results of Social Diagnosis 2015, which clearly indicates that "[over] the last two years the rate of return for all levels of studies following secondary school decreased. PhD and master's degrees retained their financial significance, but bachelor's degrees are no longer a profitable investment" [7, p. 238]. 


\section{Wykaz skrótów/List of abbreviations}

bn - bezpieczeństwo narodowe/national security;

bw - bezpieczeństwo wewnętrzne/internal security;

df - stopnie swobody/degrees of freedom;

$\mathrm{N}$ - liczebność próbki ogółem/total sample population;
$\mathrm{Nbn}$ - liczba studiujących na kierunku bezpieczeństwo narodowe/the number of students of national security;

Nbw - liczba studiujących na kierunku bezpieczeństwo wewnętrzne/the number of students of internal security; p - prawdopodobieństwo/probability; p.p. - punkty procentowe/percentage points.

\section{Literatura/Literature}

[1] Lisiecki M., Zarządzanie bezpieczeństwem publicznym, Wydawnictwo Naukowe Łośgraf, Warszawa 2011, 266.

[2] Księga dobrych praktyk w zakresie zarządzania ciągłością działania. Business Continuity Management., R.W. Kaszubski, D. Romańczuk (red.), Wydawnictwo Centrum Prawa Bankowego i Informacji Sp. z o.o., Warszawa, 15.

[3] Kęsoń T., Lutostański M., Pytania metryczkowe zamknięte z rekomendacjami do badań głównych. B. Pytania merytoryczne zamknięte (T. Kęsoń), w: Student i studiowanie bezpieczeństwa. Badania rekonesansowe. Raport Końcowy, M. Lutostański (red.), Wydawnictwo Uniwersytetu Warmińsko-Mazurskiego w Olsztynie, Olsztyn 2015, 29, 35, 50, 59, 66, 75.

[4] Kęsoń T., Lutostański M., Pytania metryczkowe zamknięte z rekomendacjami do badań głównych. A. Pytania socjodemograficzne (M. Lutostański), w: Student i studiowanie bezpieczeństwa. Badania rekonesansowe.
Raport Końcowy, M. Lutostański (red.), Wydawnictwo Uniwersytetu Warmińsko-Mazurskiego w Olsztynie, Olsztyn 2015, 16-17.

[5] Lutostański M., Nota metodologiczna, w: Student i studiowanie bezpieczeństwa. Badania rekonesansowe. Raport Końcowy, M. Lutostański (red.), Wydawnictwo Uniwersytetu Warmińsko-Mazurskiego w Olsztynie, Olsztyn 2015, 9.

[6] Kęsoń T.,Administracja i społeczeństwo w procesie zapewniania bezpieczeństwa w sytuacjach kryzysowych - wybrane problemy, w: Współdziałanie terenowych organów administracji wojskowej i administracji województwa w sytuacjach kryzysowych, K. Meszyński, M. Walancik (red.), Stowarzyszenie Ruch Wspólnot Obronnych, Warszawa 2013, 99-110.

[7] Diagnoza społeczna 2015. Warunki i jakość życia Polaków, J. Czapiński, T. Panek (red.), "Contemporary Economics, Quarterly of University of Finance and Management in Warsaw" 2015. 9(4), Rada Dialogu Społecznego, Wizja Press \&IT Warszawa 2015, 238 [dok. elektr.] http://www.diagnoza.com/pliki/raporty/Diagnoza_raport_2015. pdf [dostęp 04.12.2018].
DR INŻ. TADEUSZ KĘSOŃ - adiunkt w Katedrze Bezpieczeństwa Wewnętrznego na Wydziale Inżynierii Bezpieczeństwa Cywilnego Szkoły Głównej Służby Pożarniczej w Warszawie. Absolwent Wojskowej Akademii Technicznej, Podyplomowego Studium Bezpieczeństwa Wewnętrznego Uniwersytetu Warszawskiego oraz Marshall Center - The College of International and Security Studies - Garmisch-Partenkirchem - Executive Course 99-1. Pracownik centralnych organów administracji rządowej, w tym: Rządowego Centrum Studiów Strategicznych oraz Ministerstwa Rodziny, Pracy i Polityki Społecznej. Zajmuje się polemologią oraz szeroko rozumianym bezpieczeństwem.
TADEUSZ KĘSOŃ, PH.D. - Assistant Professor at the Internal Security Department of the Civil Safety Engineering Faculty at the Main School of Fire Service in Warsaw. He graduated from the Military University of Technology, Postgraduate Studies in Homeland Security and Marshall Center - The College of International and Security Studies - Garmisch-Partenkirchem - Executive Course 99-1. Employed at central government administration bodies, including the Government Centre for Strategic Studies and the Ministry of Family, Labour and Social Policy. His primary interests are war studies and broadly understood security and safety issues. 